\title{
KAMU ALACAĞININ KORUNMASINA YÖNELIKK BİR ÖNLEM: 6183 SAYILI KANUNA GÖRE TEMİNAT
}

DOI: https://doi.org/10.33717/ deuhfd.787686

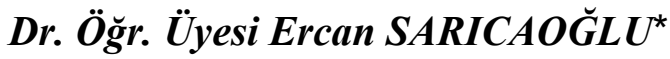

Öz

6183 sayılı Kanunda kamu alacă̆ tahsilini garanti altına almayı amaçlayan güvence önlemleri bulunmaktadır. Henüz tarh ve tahakkuk etmemiş olmasına rağmen alacă̆l güvenceye bağlayabilen koruma önlemlerinden birisi teminat kurumudur. Mahkeme kararına ihtiyaç duyulmadan idari işlem yoluyla başvurulabilen bir önlem olan teminat istemi kamu borçlusunun teminat gösterme veya göstermeme tutumuna göre farkl hukuki sonuçlara vesile olmaktadır. Çalışmamızda kendine özgü cebri takip ve tahsil süreci işletebilme olanağı sağlayabilen 6183 sayll Kanun m.9-12 arasında düzenlenmiş teminat kurumunun hukuki analiz ve tahlili yapılmaktadır.

\section{Anahtar Kelimeler}

Kamu icra hukuku, Kamu alacakları, Koruma önlemleri, Teminat, Teminat istemi

\section{A MEASURE FOR THE PROTECTION OF PUBLIC RECEIVABLE: GUARANTEE ACCORDING TO THE LAW NO. 6183}

\begin{abstract}
There are preventive regulations aimed at protecting the collection of public receivables in Law No. 6183. On of the safeguards that can tie it to the assurance that it will receive, even though it has not yet been accrued or finalized, is tha guarantee institution. Collateral request, which is a measure that can be applied thrugh administrative prooceedings without the need for a

Trabzon Üniversitesi Hukuk Fakültesi, Mali Hukuk Anabilim Dalı Öğretim Üyesi (e-posta: esaricaoglu@trabzon.edu.tr) ORCID: https://orcid.org/0000-0002-7065-3977 (Makalenin Geliş Tarihi: 27.04.2020) (Makale Gönderilme Tarihi: 04.05.2020/Makale Kabul Tarihi: 15.05.2020)
\end{abstract}


court decision has different legal consequences according to the attiutde of the public deptor th Show colleteral or not. In our study, the legal analysis and analysis of the collateral institution arranged between m.9-12 of Law Noç 6183, which can alsi provide the opporunity to operate its own forced follow-up and collection process, is carried out.

\section{Keywords}

Public enforcement law, Public receivables, Measures of conservation, Guarantee, Guarantee request 


\section{GíRiş}

Cebri takip ve tahsil sürecini yürütme yetkisine sahip kamu alacaklısı sıfatını haiz devlet soyut bir kavram olmanın ötesinde somut olarak kamu idarelerini ifade eder ${ }^{1}$. Devlet alacağının korunması fikri kapsamında farklı kanunlarda kamu alacaklısına bazı imtiyazlar tanınması kamu idarelerinin alacaklı olduğu ilişkilerde özel alacaklılar kadar dinamik yapıya sahip olmaması gibi sorunlardan kaynaklanmaktadır².

Bu kapsamda kamu alacağının cebri takip ve tahsil sürecine konu edilmesi öncesinde koruyucu nitelikte özel önlemlerin varlığg ilave güvencelerdir. Alacağın tahsil edilebilmesinde risklerin kaldırılmasını amaçlayan özel alacak-borç ilişkilerinde bile var olabilen koruyucu hükümlerin, yap1sından dolayı kamu alacaklarında ayrıcalıklı ve özel türler biçimde görünür olması mümkündür ${ }^{3}$. Bu nedenle özel hukuk kaynaklı alacaklarda bazı geçici koruma niteliğindeki uygulamalar için yargı organları tarafından verilecek kararlara ihtiyaç duyulabiliyorken kamu alacaklarına yönelik koruma önlemleri, takip ve tahsil niteliği taşımayan idari işlemler yoluyla olmaktadır ${ }^{4}$.

6183 sayılı Amme Alacaklarının Tahsil Usulü Hakkında Kanun bir taraftan iyi niyetli borçlulara kolaylık sağlamayı amaçlayan hükümleri ihtiva ederken, diğer taraftan kamu alacağının tahsilini olanaksızlaştıracak tehlikelere karşı kamu idarelerinin haklarını koruyan ve onlara ayrıcalık tanıyan önlemleri barındırmaktadır ${ }^{5}$. Kamu alacağının vadesinde tahsil edilememesinden kaynaklanan mahrumiyet ve maliyetlerin karş1lanabilmesi için gecikme zammı gibi araçların bulunmasının yanında 6183 sayılı Kanunda bu halden farklı nitelikte gelecekte tahsilin imkansızlaşması ihtimaline karşı

Yerlikaya, Gökhan Kürşat: “Türk Vergi İcra Hukukunda "Devlet” Kavramının Niteliği ve İşlevi”, Kadir Has Üniversitesi Hukuk Fakültesi Dergisi, Cilt:6, Sayı:2, 2018, s. 251.

2 Şenyüz, Doğan: "İflasta Vergi Alacakları ve Sırası", Ankara Üniversitesi Hukuk Fakültesi Dergisi, Cilt: 67, Say1: 4, 2018, s. 891.

3 Öncel, Mualla/Kumrulu, Ahmet/Çağan, Nami/Göker, Cenker: Vergi Hukuku, Gözden Geçirilmiş ve Değişiklikler İşlenmiş 28. Baskı, (Turhan Kitabevi), Ankara 2019, s. 167.

Bahçeci, Barış: Kamu Alacağının Takip Hukuku, (Seçkin), Ankara 2019, s. 156.

Şimşek, Edip: Amme Alacakları Tahsil Usulü Kanun Şerhi Uygulama ve İçtihatlar, Yeniden Gözden Geçirilmiş Güncellenmiş 2. Baskı, (Alfa Basım Yayım Dağıtım), İstanbul 1996, s. 81; Öner, Erdoğan: Vergi Hukuku, Gözden Geçirilmiş ve Güncellenmiş 11. Bask1, (Seçkin), Ankara 2019, s. 193; Gerçek, Adnan: Kamu Alacaklarının Tahsil Hukuku, 5.Baskı, (Ekin), Bursa 2017, s. 159; Karadağ, Neslihan Coşkun: "Vergi Alacağının Güvence Altına Alınmasında Teminat, İhtiyati Haciz ve İhtiyati Tahakkuka İlişkin Özellikli Durumlar”, Maliye Dergisi, Sayı: 162, 2012, s. 239. 
kamu alacaklısına güvence veren hükümler vardır ${ }^{6}$. Burada tahsilin tehlikeye girme ihtimalinde olmasına istinaden özel güvence önlemleri uygulayabilecek hukuki araçlara sahip olunmaktadır.

Kamu alacaklarının korunmasına yönelik hükümler 6183 sayılı Kanunun "Amme alacaklarının korunması" bölümü içerisinde yer almaktadır. Ayrıca kamu alacağının doğumundan tahsiline kadar ki süreç için bu bölümde yer alanlarla sınırlı olmayan farklı hukuki düzenlemelerle de karşılaş1labilmektedir ${ }^{7}$. Bu düzenlemelerden bazıları henüz kamu alacağının kesinleşmesini beklemeden alınabilecek önlemleri bazıları ise kamu alacağı kesinleştikten sonra borcun ödenmesine yönelik uygulanacak hükümleri ifade etmektedir ${ }^{8}$.

6183 sayılı Kanunda yer alan teminat kurumu, vergilendirme işlemleri dahil henüz kesinleşmemiş kamu alacakları için kesinleşme öncesi bir zamanda alacağın tahsilini garanti altına almayı amaçlayan bir önlemdir ${ }^{9}$. Kendine özgü cebri takip ve tahsil süreci işletebilmeyi olanaklı kılan teminat kurumu, diğer koruma önlemlerine göre daha kısa sürede ve daha kolay tahsil sağlayabilmektedir. Bu kapsamda kamu alacağı için teminat gösterilmişse teminatın paraya çevrilerek alacağın tahsili yoluna gidilebilmektedir ${ }^{10}$. Ayrıca teminat diğer koruma önlemlerine unsur olma gibi bir özelliğe sahiptir.

Diğer taraftan mali mevzuatımızda teminat adı ile anılan farklı düzenlemeleri 6183 sayılı Kanunda yer alan teminat kurumundan ayırt etmek gerekir $^{11}$. Belli imkânlardan yaralanabilmenin karşllığında bir şart olarak ileri sürülebilen teminat halleri (VUK, m.376, 6183 sayılı Kanun m.48 vd.)

Öncel/Kumrulu/Çağan/Göker, s. 179; Karakoç, Yusuf: Kamu İcra Hukuku, (Yetkin), Ankara 2016, s. 111.

7 Öncel/Kumrulu/Çağan/Göker, s. 182; Karakoç, Yusuf: Genel Vergi Hukuku, Gözden Geçirilmiş ve Güncellenmiş 2. Baskı, (Yetkin), Ankara 2019, s. 511; Çelik, Binnur: Kamu Alacaklarının Takip ve Tahsil Hukuku, 3.Baskı, (Onikilevha), İstanbul 2018, s. 36; Taşkan, Yusuf Ziya: Vergi Hukuku, Genişletilmiş ve Gözden Geçirilmiş 2. Baskı, (Adalet), Ankara 2019, s. 306; Üstün, Ümit Süleyman: Kamu Alacaklarında Rüçhan Hakk1, (Legal), İstanbul 2013, s. 54.

8 Arslaner, Hakan: 6183 sayılı Kanun Kapsamında Kamu Alacaklarının Haciz Yoluyla Tahsili, (Yetkin), Ankara 2010, s. 147.

9 Üstün, Kamu Alacakları, s. 55; Öner, s. 194.

10 Barlass, İrfan: Kamu Alacaklarının Haciz Yoluyla Takibi, (Onikilevha), İstanbul 2017, s. 16.

11 Mali hukuk içinde değerlendirilebilen tüm teminat kurumlarına yönelik ayrıntılı bilgi için bknz. Gerçek, Adnan: Türk Mali Hukukunda Teminat, (Seçkin), Ankara 2013. 
ile VUK, m.153/A'de yer alan teminat kurumlarının, farklı nitelikte olduğunun altı çizilmelidir ${ }^{12}$.

Çalışmamızda kamu alacaklısının karşılaşabileceği tehlikelerle alacağını tahsil edememe riskine yönelik olarak kendisine güvence verilmesini amaçlayan koruma önlemlerinden 6183 sayılı Kanun m.9-12 arasında düzenlenmiş teminat kurumu ele alınmaktadır.

\section{HUKUKİ NITTELIĞİ}

Teminat kelimesi, güvence anlamını ihtiva eder ${ }^{13}$. Bu kavram, özünde bu karşılığı bulacak şekilde farklı alanlarda kullanılabilmektedir. Hukuki olarak teminat, zamanında veya uygun surette elde edilme riski taşıyan bir alacağın ödenmesini veya hukuki bir durumun gerçekleşmesini güvenceye bağlamak için alınan karşılık/iktisadi değer olarak ifade edilebilir ${ }^{14}$. Diğer taraftan teminat kavramı farklı hukuk alanlarında farklı 1stılah anlamı ihtiva eden surette de yer alabilmektedir.

6183 sayılı Kanunda tanımı yapılmamış olan teminat, kamu alacağının tahsilinin tehlikeye girdiği veya tehlikeye girdiğinin kabul edildiği nedenlere dayalı olarak kamu alacaklısının isteği üzerine borçlunun malvarlığındaki kıymetlerden Kanunda belirtilenler arasından kendi seçtiklerini borcuna karşılık göstererek, kamu alacağının güvence altına alınması olarak tarif edilebilir $^{15}$. Bu haliyle mükellefin bazı olanaklardan yararlanabilmek için idareye sunduğu değerlerden tamamen bambaşka bir anlama sahip 6183 sayılı Kanun m.9-12 arasında yer alan teminat kurumu, kamu alacaklarının tahsilini koruma altına alan bir güvence önlemi olarak kavramsallaşmaktadır.

6183 say11 Kanunda yer alan teminat kurumunun amac1 Kanunda yer alan ifadelerle karşılığını bulabilmektedir. Zira "Amme alacaklarının korunması" bölümü içerisinde kavram olarak güvence anlamını ihtiva eden "teminat hükümleri” başlığı altında yapılabilecek düzenlemelerin hedefi bellidir.

12 Karakoç, Kamu İcra, s. 112; Bayraklı, Hasan Hüseyin: Vergi İcra Hukuku, Afyonkarahisar 2012, s. 32; Gerçek, Kamu Alacakları, s. 161.

13 TDK, Güncel Türkçe Sözlük, https://sozluk.gov.tr/ (15.02.2020).

14 Karakoç, Kamu İcra, s. 111; Bayraklı, s. 31; Gerçek, Teminat, s. 21; Coşkun, Mahmut: Açıklamalı-I̧çtihatlı Amme Alacaklarının Tahsil Usulü Hakkında Kanun, Güncelleştirilmiş 2. Bask1, (Seçkin), Ankara 2013, s. 125; Üstün, Ümit Süleyman: "Kamu Alacaklarının Korunması Bakımından Teminat Kurumu", Vergi Sorunları Dergisi, Sayı:182, 2003, s. 147; Yapar, Burcu Kuzucu: Türk Hukukunda Kamu Alacaklarını Güvence Altına Alan Önlemler, (Onikilevha), İstanbul 2020, s. 87.

15 Karakoç, Kamu İcra, s. 111; Bayraklı, s. 31; Çelik, Kamu Alacakları, s. 40; Gerçek, Kamu Alacakları, s. 160; Arslaner, s. 148; Üstün: Teminat, s, 147; Yapar, s. 88. 
Kamu alacaklarını güvence altına alma amacı taşıyan teminat, borçluya olan güvensizlikten kaynaklanmaktadır. Kanun koyucu, üstün ve ayrıcalıklı yetkilerle donattığı kamu alacaklısının hazineye intikal edecek gelir beklentisinin, kamu borçlusunun olası hukuka aykırı tutumundan etkilenmemesini amaçlayarak kamu alacaklısına teminat isteme hak ve yetkisi tanımıştır. Diğer taraftan bazı durumlarda bu hak ve yetki aynı zamanda kamu alacaklısının sorumluluğuna neden olabilecek bir zarureti de ifade etmektedir.

Teminat istemi ile kamu alacaklısı tasarrufuna alabileceği bir değer beklentisi içinde somutlaşan bir istek ile bireye külfet yüklenmektedir. Doğmas1 muhtemel kamu borcu için teminat istemi süreci sonunda elde edilecek teminat sayesinde, kamu alacağı kesinleştiğinde borçlunun borcunu ödememe riskiyle karşı karşıya kalabilecek kamu alacaklısı, özel cebri takip ve tahsil uygulayabilme yetkisini elinde tutarak kamu alacağının tahsilini garanti edebilmektedir.

6183 sayılı Kanunda yer alan teminat, aynı bölümde düzenlenmiş olan ihtiyati haciz ve ihtiyati tahakkuk kurumlarından daha hafif nitelikte ve hukuki sonuçları bunlara nazaran daha sınırlı olan bir güvence önlemidir. Kamu borçlusu teminat ile sadece kamu alacaklısı tarafından belirlenmiş borçla sınırlı olarak, kendi iradesiyle seçtiği unsurları teminat olarak sunma imkânına sahip olmaktadır ${ }^{16}$. Ayrıca kamu alacağını teminata bağlamak diğer önlemelere başvurmayı veya diğer takip ve tahsil usullerini işletmeyi gereksiz kılabilmektedir. Kamu alacağı kesinleştiğinde kamu borçlusunun borcunu ödememesi üzerine teminatın paraya çevrilmesi usulüyle alacak tahsil edilebilmektedir. Böylece hem kamu borçlusu farklı hukuki süreçlere muhatap olmayacak hem de kamu alacaklısı alacağına daha çabuk, daha az masrafla ve daha kolay bir yolla ulaşabilecektir ${ }^{17}$.

Teminat, kamu alacağının tahsilini zorlaştırmak için borçlunun malvarlığını azaltması, kaçırması veya başka tutumlarıyla tahsilin zamanında ve uygun surette yapılmasına engel olacağ ${ }_{1}$ endişelerine istinaden başvurabilen bir güvenlik önlemidir ${ }^{18}$. Kamu borçlusuna geleceğe yönelik soyut bir tehlike ihtimaline karşılık yükletilen bu külfet için güvensizliğin görünüş itibariyle somut ve kabul edilebilir gerekçelerinin olmasını beklemek gerekir. Kanun koyucu 6183 sayılı Kanunda yer alan düzenlemelerle belli nedenleri kamu alacağının tahsili için kendiliğinden tehdit olarak kabul etmişken, belli

\footnotetext{
Coşkun, s. 125.

Karakoç, Kamu İcra, s. 112; Bayraklı, s. 31; Gerçek, Kamu Alacakları, s. 160.

Koçak, Muhsin: Vergi-İ́cra Hukuku, Güncellenmiş 2. Baskı, (Seçkin), Ankara 2018, s. 105.
} 
haller ise kamu alacaklısının ayrıca araştırmakla yükümlü olduğu durumlar olarak belirginleşmektedir.

Kamu alacaklısı teminat isteme yetkisini kullanarak kamu borçlusundan talepte bulunur. Bu haliyle kamu idaresi teminat istemiyle malvarlığı üzerinde doğrudan doğruya alınmış bir önlem, malvarlığının aktifi ve tümüyle ilgili bir işlem, icrai bir fiil gerçekleştirmiş olmamakta, sübjektif bir iradeyle teminat istenerek sadece belirli kişi ve olaylar hakkında hukuki sonuç doğuracak talep iletilmektedir ${ }^{19}$. Kamu alacaklıs1, kanunun kendisine tanıdığ1 imkân dahilinde idari işlem yoluyla teminat istemekte, kamu borçlusu ise kendi tercih ettiği iktisadi değeri teminat olarak göstererek mülkiyet hakkından kaynaklanan yetkilerini sınırlandırmakta veya teminat göstermeyerek farklı hukuki sonuçların doğmasına sebebiyet vermektedir.

Kamu alacaklısına imtiyaz tanıyan ve kamu borçlusuna külfet yükleyen böyle bir kurumun hukuki dayanağı şüphesiz kanun olmalıdır. 6183 sayılı Kanun m.9'da teminat isteme, m.10'da teminat ve değerlemesi, m.11'de şahsi kefalet, m.12'de teminat hükmünde olan eşya konuları yer almaktadır. Diğer taraftan vergi idaresinin 6183 sayılı Kanuna dair uygulamasını şekillendiren Tahsilat Genel Tebliği Seri: A Sıra No:1 tebliğinde, Kanunun teminat kurumu ile ilgili hükümlerinin uygulamasına yönelik vergi idaresi görüşü ve açıklamaları bulunmaktadır.

\section{TEMINAT İSTEME}

\section{A. Genel Olarak}

6183 sayılı Kanun m. 9 "Teminat isteme” kenar başlığı altında yer alan düzenlemelerden teminatın hangi koşullar altında kim tarafından ve nasıl istenebileceğine yönelik tespitler yapılabilmektedir. Bu doğrultuda bu başlık altında teminat isteme koşulları, teminat isteme yetkisi ve teminat isteme usulü ele alınacaktır. Ancak Kanun hükmünün tüm soruların cevabına ulaşma imkânı vermediğini ve bazı konularda tartışmalar bulunduğunu ifade etmek gerekir.

6183 sayılı Kanun m.9'da iki fikra düzenlemesi bulunmaktadır. İlk fikra düzenlemesi 213 sayılı VUK kapsamına giren kamu alacaklarıyla ilgilidir. Diğer fikra ise tüm kamu alacaklarını kapsamaktadır ${ }^{20}$. Birinci fik-

Çelik, Kamu Alacakları, s. 41; Üstün, Teminat, s. 147; Gerçek, Kamu Alacakları, s. 161; Arslaner, s. 148; Karadağ, s. 240.

20 Karakoç, Kamu İcra, s. 112; Candan, Turgut: Açıklamalı Amme Alacaklarının Tahsil Usulü Hakkında Kanun, Güncelleştirilmiş 3. Baskı, (Mali Akademi Yayınları), Ankara 2007, s. 82; Çelik, Kamu Alacağı, s. 42; Yapar, s. 88-89. 
rada yer alan koşulların varlığında teminat istenmesi zorunlu olmakla beraber ikinci fikraya göre idarenin takdirine bağlı olarak teminat istenebilmektedir $^{21}$. Ayrıca birinci fikrada Kanunda yazılı nedenlerin varlığı halinde alacağın tahsil tehlikesi içinde bulunduğu Kanun koyucu tarafindan doğrudan kabul edilmiştir. İkinci fikraya göre ise kamu alacağının tahsilinin tehlikede olduğu tespit edilirse teminat isteme yetkisi doğacaktır.

\section{B. Teminat İsteme Koşulları}

Kamu alacağ 1 kesinleşmeden başvurulabilen bir güvence önlemi olan teminat istemi için Kanunda yer alan belirli koşullar gerçekleşmiş olmalıdır. $\mathrm{Bu}$ haliyle kamu alacaklisina teminat isteme yetkisi verecek olan hukuki sebep teminat isteme koşullarının vuku bulmuş olmasıdır. 6183 sayılı Kanun m.9/1 ve m.9/2'de farklı koşullara bağlı olarak teminat istenebilmektedir.

6183 sayılı Kanun m.9/1'de yer alan koşular; teminat isteme nedeninin var olması, teminat isteme nedeninin ve teminata esas alınacak tutarın vergi incelemeye yetkili memurlarca tespit edilmesi, bu tespitin tahsil dairesine bildirilmesi ve talepte bulunulması, kamu alacağının salınması için gerekli işlemlere başlanılmış olunmasıdır. 6183 sayılı Kanun m.9/2 de yer alan koşullar ise kamu borçlusunun Türkiye'de ikametgâhının bulunmaması ve bu halin kamu alacağı tahsilinin tehlikede olduğunu göstermesidir.

6183 sayılı Kanun m.9/1 hükmüne göre teminat isteminin ilk koşulu, kanunda yer alan teminat isteme nedenin ortaya çıkmış olmasıdır. Buna göre böyle bir nedenin var olmadığ bir olayda teminat istenemeyecektir. Teminat istemine yönelik neden ihtiva eden 6183 sayılı Kanun m.9/1'de şu ifadeler yer almaktadır:

"213 say1l Vergi Usul Kanunun 344. maddesi uyarnnca vergi ziya1 cezası kesilmesini gerektiren haller ile 359. maddesinde sayılan hallere temas eden bir kamu alacağının salınması için gerekli olan muameleler başlanmış olduğu takdirde vergi incelemesine yetkili memurlarca yapılan ilk hesaplara göre belirtilen miktar üzerinden tahsil dairesince teminat istenir."

$\mathrm{Bu}$ hükmün içeriğinde teminat istemi için iki farklı nedenin olduğu ifade edilmektedir ${ }^{22}$. Diğer taraftan "ile" bağlacının "ve" olarak değerlendirilmesi ile VUK, m.344 uyarınca vergi ziya1 cezası gerektiren hallerin ve

Karakoç, Kamu İcra, s,.113; Candan, s. 87; Koçak, s. 112, Öner, s. 195.

Kaneti, Selim/Ekmekçi, Esar/Güneş, Gülsen/Kaşıkçı, Mahmut: Vergi Hukuku, (Filiz Kitabevi), İstanbul 2019, s. 571; Candan, s. 83; Çelik, Kamu Alacakları, s. 41; Gerçek, Kamu Alacakları, s. 162; Coşkun, s. 126; Ünsal, Hilmi: Amme Alacaklarının Takip ve Tahsili, Damga Vergisi ve Harçlar, (Seçkin), Ankara 2019, s. 19. 
VUK, m.359 maddesi gereğince kaçakçılık suçu oluşturan durumların birlikte gerçekleşmiş olmasının gerekli olduğu da ileri sürülmüştür ${ }^{23}$. Bu doğrultuda öncelikle Kanunda ifade edilen durumların ayrı ayrı mı değerlendirileceği yoksa burada Kanun koyucunun sadece VUK, m.359'daki fiillerle işlenen vergi ziya1 cezası halini mi bir neden olarak kabul ettiği tespit edilmelidir.

Tahsilat Genel Tebliğinde, 6183 sayılı Kanunda yer alan "ile" ifadesi yerine "ve" kelimesi kullanılarak Kanunda yer alandan farklı bir düzenlemeye yer verilmiştir ${ }^{24}$. Ancak vergi idaresinin bu farklı yazımın sonuçlarının farkında olacak şekilde bir yaklaşım geliştirdiği, bu konuda bilinçli bir tercihte bulunduğu ve daha önemlisi vergi idaresinin açıklama niteliğini haiz bir tebliğ yoluyla böyle bir uygulamayı kabul etme yetkisi tartışılacak meselelerdir.

Ancak şurası gerçektir ki ağır sonuçlar yükümlendiren, farklı yorumlara sebebiyet verebilen bu durumu açıklığa kavuşturacak belirgin bir kanuni düzenlemeye ihtiyaç duyulmaktadır ${ }^{25}$.

Diğer taraftan mevcut düzenlemenin değerlendirilmesi ise Kanun koyucunun iradesinin ortaya çıarılması halinde mümkün olabilmektedir. Bu

23 Bu yöndeki tartışmalar için bknz. Bahçeci, s. 165-166; Taylar, Yıldırım: "Kamu Alacakları İçin Güvence Önlemi Olarak Teminat ve Teminat-İhtiyati Haciz İlişkisinden Kaynaklanan Sorunları", Mali Pusula, S:48, 2008, s. 79-80; Yapar, s. 91-92; Şeker, Sakıp: "Vergi İncelemelerine Dayanan İhtiyati Haciz Uygulamalarının Mükellef Hakları Yönünden Değerlendirilmesi”, Legal Mali Hukuk Dergisi, Sayı:37, 2008, s. 160-161; Arslan, Cem Barlas: "Kamu Alacağını Güvence Altına Alınmasında Teminat Uygulaması", Legal Mali Hukuk Dergisi, Sayı:60, 2009, s. 2475; Baysal, Eda: "Vergi Hukuku Yönünden Amme Alacağının Korunmasına Dair Güvence Önlemlerinden Olan "Teminat İsteme" Uygulamasında "Yetki" ve "Neden" Unsurlarının Tahlili", Legal Mali Hukuk Dergisi, Sayı: 54, 2009, s. 1168-1169; Şentürk, Akın Gencer: "Amme Alacaklarının Korunması Yöntemlerinden "Teminat İsteme" Uygulamasının İhtiyati Tahakkukİhtiyati Haciz Müesseseleri İle Bağlantısının Ortaya Konulması ve Bir İdari İşlem Olarak Vergi Hukuku Yönünden İrdelenmesi”, s. 15, http://agencerhukuk.com/014.pdf (20.02.2020).

24 “... Buna göre, 213 sayılı Kanunun 135 inci maddesiyle kendilerine inceleme yetkisi verilmiş bulunanlar tarafindan mükelleflerin veya sorumluların kayıt ve işlemlerinin incelenmesi sirasinda 213 sayıl Kanunun 344 ve 359 uncu maddelerinde sayılan hallerin tespit edilmesi nedeniyle bir amme alacağı salınması için gereken işlemlere başlanılmışsa, inceleme elemanlarınca yapılacak ilk hesaplara göre tespit edilecek tutar üzerinden derhal teminat istenecektir."

25 Çelik, Binnur: "Kamu Alacaklarını Güvence Atına Alan Teminat, İhtiyati Haciz ve İhtiyati Tahakkuk Uygulamaları ve Kanun Değişikliği Önerileri”, Amme Alacaklarının Tahsil Usulü Hakkında Kanun İle Bağlantılı Problemler ve Çözüm Paneli, (İstanbul Vergi Merkezi), İstanbul 2018, s. 1. 
doğrultuda vergi idaresinin konuya yeknesak bir yaklaşım sergileyebileceği açıklıkta olmayan 6183 sayılı Kanunun ilgili düzenlemesi karşısında hangi neden veya nedenlerin teminat istemine dayanak olabileceği ortaya konulmalıdır. Zira bu düzenlemede farklı iki nedenin olduğu kabul edilirse herhangi bir vergi ziyal halinin teminat istemi için yeterli olduğu söylenebilecekken, diğer durumda ise sadece vergi kaçakçıllğı teşkil eden fiillerle vergi ziyauna sebebiyet verilen haller teminat isteme nedeni olabilecektir.

VUK, m.344 "vergi ziyaı cezası" kenar başlıklı düzenlemede ${ }^{26}$, vergi ziyaı cezası kesilmesini gerektiren üç farklı husus düzenlenmiştir. Buna göre ziyaa uğratılan verginin birinci fikrada yer alan hallerde tek kat, ikinci fikrada yer alan hallerde üç kat, üçüncü fikrada yer alan hallerde ise yüzde elli oranında ceza uygulanması gerekir. Bu düzenlemelerde vergi zıya1/kaybı neticesi hedef tutularak, farklı sebeplerle neden olunan bu neticeye karşı farklı tutarlarda ceza miktarı öngörülmüştür.

6183 say1l Kanun m.9/1'de yer alan "213 sayıl1 Vergi Usul Kanunun 344. maddesi uyarınca vergi ziya1 cezası kesilmesini gerektiren haller ..." ifadesi esasinda VUK, m.359'da sayllan hallere temas eden kamu alacakların da kapsamaktadır. Zira VUK, m.344/2'e göre; 3 kat tutarında vergi ziya1 cezası kesilmesine neden olan VUK, m.359'da yaz1l olan fiillerle vergi ziyaına sebebiyet verilmesi halidir. Diğer bir ifadeyle 6183 sayılı Kanun m.9/1'de yer alan " ... 359. maddede sayılan hallere temas eden bir kamu alacağı" ifadesi zaten öncesinde sayılmış bulunan VUK, m.344 içinde yer alan ikinci fikra düzenlemesinde vardır. Ayrıca bu fiillerin kasıtlı işlenmediği tespitiyle tek kat vergi ziyaı cezası kesilmesine neden olan haller de VUK, m.344'ün birinci fikrası içinde değerlendirilmektedir.

Diğer taraftan VUK, m.359'da yazılı fiillerle her durumda bir kamu alacağına sebebiyet verilemeyeceğinin 6183 sayılı Kanunda vergi kaçakçılığı teşkil eden bir fiilin değil kamu alacağı doğuran bir olayın arandığının altını çizmek gerekir. Bu doğrultuda örneğin, kamu alacağı doğumuna neden

213 sayılı VUK, m.344'de yer alan hüküm şu şekildedir;

"341 inci maddede yazılı hallerde vergi ziyaına sebebiyet verildiği takdirde, mükellef veya sorumlu hakkında ziyaa uğratılan verginin bir katı tutarında vergi ziyaı cezası kesilir.

Vergi ziyaına 359 uncu maddede yazılı fiillerle sebebiyet verilmesi halinde bu ceza üç kat, bu fiillere iştirak edenlere ise bir kat olarak uygulanır.

Vergi incelemesine başlanılmasından veya takdir komisyonuna sevk edilmesinden sonra verilenler hariç olmak üzere, kanuni süresi geçtikten sonra verilen vergi beyannameleri için bu madde uyarınca kesilecek ceza yüzde elli oranında uygulanır." 
olmayan bir hesap ve muhasebe hilesi için teminat isteme nedeni oluşmayacaktır.

$\mathrm{Bu}$ haliyle teminat istemi nedeni konusunda tereddüt oluşması pek mümkündür. Kanun lafzının açık bir saptama yapma imkânı vermediği böyle bir durumda hükmün gerçek anlamı tespit edilmelidir. Bunun için öncelikle Kanun metninin günümüze gelene kadarki süreçte geçirdiği evrime bir göz atılmalidır.

6183 sayılı Kanun m.9/1 değişikliklere uğramış bir hükümdür. Teminat kurumunun ilk halini ihtiva eden 28.07.1953 tarihli Resmî Gazetede yayınlanmış 21.07.1953 tarih ve 6183 sayılı Kanun, m.9'da şu ifadeler yer almaktaydi:

"Vergi Usul Kanununun 324 üncü maddesinde sayılan hallere temas eden bir âmme alacağının salınması için gereken muamelelere başlanmış olduğu takdirde, vergi incelemesine salahiyetli memurlarca yapılan ilk hesaplara göre belirtilen miktar üzerinden tahsil dairelerince teminat istenir."

Bu Kanun hükmünde atıf yapılan 15.06.1949 tarihli Resmî Gazetede yayınlanmış 07.06.1949 tarih ve 5432 sayılı Vergi Usul Kanunu m.324'de kaçakçıllı teşkil eden eylemler bulunmaktaydı. Burada yer alan VUK düzenleme sisteminde vergi cezalarına yönelik; kaçakçılık-kusur-usulsüzlük tipleri yer alıyordu. Kanunda kaçakçılık; vergi kaçırma kastı ile kanunda sayılan şekillerde vergi ziyauna sebebiyet verilmesi olarak tarif edilmekteydi.

Değişiklik ihtiva eden 2347 sayılı Kanun ile 6183 sayılı Kanun m.9/1 hükmünde yapılan düzenleme sonrası Kanun metni şu hale gelmiştir:

"Vergi Usul Kanununun 344 ncü maddesinde sayılan kaçakçılık halleriyle mükerrer 347 nci maddesinin 1 numaralı bendinde belirtilen hallere temas eden bir amme alacağının salınması için gerekli muamelelere başlanmış olduğu takdirde vergi incelemesine yetkili memurlarca yapılan ilk hesaplara göre belirtilen miktar üzerinden tahsil dairelerince teminat istenir."

$\mathrm{Bu}$ düzenlemede atıf yapılan Vergi Usul Kanunumuzun yürürlükten kaldırılmış vergi ceza sisteminde ise VUK, m.344'de 6 bent halinde sayılan fiillerden herhangi birisi ile vergi ziyanna sebebiyet verildiğinde kaçakçıllk oluşmaktaydı. Mükellefin tedbirsizliği ve işlerine gerekli özeni göstermemesi sonucu kaçakçılığa nazaran daha hafif bir şekilde meydana çıkan bir vergi kaybına sebebiyet verme fiili ise ağır kusur olarak kavramsallaşmıştır. Bu halde kaçakçıllık ve ağır kusur (sadece VUK, mülga mükerrer 3471 inci bentte sayılan) teminat istemi nedeni olabilmekteydi. 
6183 say11 Kanunun ilk halinde "kusur" ${ }^{27}$ teminat istemine neden olabilecek hallerin dışında tutulmuş sadece kaçakçılık yer almıştır. Sonraki düzenlemede ise kaçakçılık ve ağır kusur teminat istemi nedeni olarak öngörülmüştür. Burada Kanun koyucu önceki Vergi Usul Kanunu düzenlemesinde yer almayan yeni bir tür ağır kusuru, teminat istemi nedeni olarak ilave etmiştir. Diğer bir deyişle ilk düzenlemede sadece kaçakçıllk teşkil eden fiillerle vergi kaybına yol açan durumlar teminat istemi içine dahil edilirken, sonraki düzenlemede o anki kanun sistematiğinde sadece kaçakçıllk teşkil eden fiillerle vergi ziyaına yol açılması değil, sınırlanmış ve belirlenmiş eylemden kaynaklanan ağır kusurla vergi ziyaına neden olma hali de teminat isteme kapsamına dahil edilmiştir.

Ancak dikkat çekici olan bu düzenlemelerin ortak özellĭgi o anki Vergi Usul Kanunu düzenlemelerine göre vergi ziyaı cezası kesilmesi gerektiren tüm hallerin teminat istenebilecek nedenler olarak kabul edilmemiş olmasidır.

Halihazırda Vergi Usul Kanunumuzun cezalandırma sistemi bu Kanunların yürürlükte olduğu dönemlerden tamamen farklıdır ${ }^{28}$. Teminat isteme nedenlerini belirleme konusunda bu değişim dikkate alınmalıdır. Şu an ki düzenlemeler çerçevesinde vergi suçu-vergi kabahati ayrımının olduğu, vergi kaçakçıllğının (VUK, m.359) bir vergi suçu tipi olarak öngörüldüğü, bu suçun oluşumunda vergi zıyaının suçun bir unsuru olmaktan çıkarılmış olduğu hususlarının altını çizmek gerekir.

$\mathrm{Bu}$ durumla birlikte yukarıda ifade edilen mülga kanunlar üzerinden değerlendirme yapıldığında Kanun koyucunun tüm vergi ziyaina yol açan halleri değil özelde sadece vergilendirme alanında ağır ihlal olarak nitelediği vergi kaçakçıllğı teşkil eden fiillerle vergi ziyaına yol açan halleri teminat isteyebilecek neden olarak öngörmek istediği çıkarımı yapılabilmektedir. Ancak diğer taraftan Kanun koyucunun 2346 sayılı Kanunla değişiklik yaptığı düzenlemeyle ağır kusuru da teminat isteyebilecek bir hal olarak kapsama dâhil etmesi tedrici olarak teminat isteme nedenlerini genişletme iradesi taşıdığını ve bu son düzenlemeyle tüm vergi kaybına yol açan

27 VUK, mülga m.329: "Kusur, kaçakçılık sayılan haller dışında herhangi bir suretle vergi ziyama sebebiyet verilmesidir."

286183 say1l Kanun m.9/1'de yer alan "Vergi Usul Kanununun 344 üncü maddesinde sayılan kaçakçılık halleriyle mükerrer 347 nci maddesinin 1 numaralı bendinde belirtilen..." ibaresi, 22.07.1998 tarih ve 4369 sayllı Kanun m.81 hükmüyle "213 sayılı Vergi Usul Kanununun 344 üncü maddesi uyarınca vergi ziyaı cezası kesilmesini gerektiren haller ile 359 uncu maddesinde sayılan...” olarak değiştirilmiş ve Kanun metnine işlenmiştir. 
nedenleri teminat isteme nedeni olarak oluşturmak istediği sonucuna da ulaşılabilmektedir. Fakat bu sonucu doğrulayacak farklı somut dayanaklara ihtiyaç duyulduğu da bir gerçektir.

Burada teminat istemi nedeninin VUK, m.359'da yer alan fiillerle işlenen vergi zıyaı cezası halleri olduğu düşünülmektedir. Zira 6183 sayılı Kanun m.9/1'de VUK, m.344 bulunmasına rağmen, VUK, m.344 kapsamına giren VUK, m.359'da sayılan hallerle kamu alacağına sebebiyet verilmesi durumunun ayrıca yazılmıs olması Kanun koyucunun vergi ziyaı cezası gerektiren tüm halleri teminat istemi nedeni olarak öngörmeme iradesinden kaynaklanmaktadır.

Kanun koyucu abesle iştigal etmeyecektir. Vergi ziyaı cezası kesilmesi gerektiren tüm haller teminat isteme nedeni olarak düzenlenmek istenseydi Kanunda sadece VUK, m.344'ün bulunmasıly yetinilebilecektir. Bu hükme ilave olarak VUK, m.359'un ayrıca yazılmış olması buradan kaynaklanan vergi ziyaı hallerine odaklanıldığını göstermektedir. VUK, m.359'da yer alan vergi kaçakçıllı̆̆ suçu teşkil eden ve oluşumu için vergi zıyaının şart olmadığ yapıda olması da bu durumu doğrulamaktadır. Son olarak mülga kanun düzenlemelerinin tüm vergi kaybına yol açan nedenleri teminat isteme nedeni olarak düzenlememiş olması bu sonuca ulaşılmasına vesile olmaktadır. Buna göre VUK, m.359'de yazılı fillerle neden olunan vergi ziya1 cezası kesilmesini gerektiren bir kamu borcunun yükletilmesi durumlarında teminat isteme nedeninin var olacağı düşünülmektedir.

Teminat istemi için bir nedenin var olması tek başına yeterli değildir. $\mathrm{Bu}$ nedenin oluştuğu konusunda Kanunda öngörülen biçimde tespit yapılmalıdır. 6183 sayılı Kanun m.9/1 çerçevesinde teminat istemenin bir koşulu olarak, teminat isteme nedeninin öncelikle vergi incelemesine yetkili memurlarca ortaya konulmasi gerekmektedir.

Teminat istenilmesinin bir koşulu olan nedenin var olduğu, ilk olarak vergi incelemesine yetkili memurlarca belirlenmeli ve onlarca yapılacak ilk hesaplamalara göre teminata esas alınacak tahmini bir tutar somutlaştırılmalıdır ${ }^{29}$. Vergi incelemesi yapmaya yetkili olan; vergi müfettişleri, vergi müfettiş yardımcıları, ilin en büyük mal memuru, vergi dairesi müdürleri, Gelir İdaresi Başkanlığının merkez ve taşra teşkilatında müdür kadrolarında görev yapanlar ile VUK, m.72 uyarınca kurulan takdir komisyonları

29 Kızılot, Şükrü/Kızlot, Zuhal: Vergi İhtilafları ve Çözüm Yolları, Güncellenmiş 15. Bask1, (Yaklaşım), Ankara 2009, s. 480; Gerçek, Kamu Alacakları, s. 162; Öner, s. 195. 
tarafindan Kanunda yer alan nedenin oluştuğu saptanarak, ilk hesaplama gerçekleştirilmelidir ${ }^{30}$.

Teminat istemenin gerekli olduğu durumları ilk öğrenebilecek olan kişilerin vergi incelemesi sırasında vergi incelemeye yetkili olan memurlar olduğu düşünüldüğünde burada tutarlı bir düzenleme bulunmaktadır. Vergi incelemesine yetkili olmayanların yapacağ istemine dayanak teşkil edemeyecektir. Diğer taraftan 6183 sayılı Kanunda odaklanılan vergi inceleme süreci değil, vergi incelemeye yetkili olan kişilerdir. $\mathrm{Bu}$ doğrultuda vergi incelemesi dışındaki herhangi bir süreçte vergi incelemesi yapmaya yetkili kişilerce yapılacak tespit ve hesaplamaların bu koşulu sağlayabileceği gibi bir düşünce oluşabilmektedir. Ancak vergi hukuku sistemimiz açısından VUK, m.344 ile VUK, m.359 hükümlerindeki hallere yönelik bir tespit yapılabilmesi, kamu alacağı için gerekli işlemlere başlanabilmesi ve vergi incelemesine yetkili memurlar tarafindan bir hesaplama yapılabilmesi için mükellef ve sorumluların kayıt ve işlemlerine yönelik bir vergi incelemesi yapılmalıdır. Bu halde doğrudan Kanunda yer alan ifadelerden anlaşılmamakla birlikte teminat isteminin temelinde sebep ve sonuçları itibariyle bir vergi incelemesi bulunması zorunludur.

Buna göre teminat istemi için öncelikle bir vergi incelemesi olmalıdır. Yoklama veya diğer denetim yollarında teminat istemek mümkün değildir ${ }^{31}$. Ayrıca bir vergi incelemesinin bulunması tek başına teminat isteme nedeni olmayıp Kanunda yer alan tüm koşullar sağlanırsa teminat istenebilecektir ${ }^{32}$.

$\mathrm{Bu}$ halde vergi incelemesi yapmaya yetkili memurlar tarafindan vergi incelemesi sırasında kayıt ve işlemler üzerinden teminat isteme nedeninin var olduğu tespit edilmeli ve bu kişilerce ilk hesaplamalara göre teminata esas alınacak tutar belirlemesi yapılmalıdır.

6183 sayılı Kanun m.9/1'e göre diğer bir koşul vergi incelemeye yetkili kişilerce teminat isteme nedeni ve tutar belirlemesi yapıldıktan sonra bu hususun tahsil dairesine bildirilerek, talepte bulunulmasıdır. Tahsil dairesine

30 Candan, s. 84; Yapar, s. 89.

31 Doğrusöz, Bumin: "Vergi Dairesinin Teminat Talebi”, Dünya Gazetesi, 13 Mayıs 2015, https:/www.dunya.com/kose-yazisi/vergi-dairesinin-teminat-talebi/23939.

(20.02.2020); Danıştay 4.D. T.13.9.1976, E.1975/2990, K.1976/1881 için bknz. Ünlü, M. Cengiz: Açıklamalı-İçtihatlı Amme Alacaklarının Tahsil Usulü Hakkında Kanun, (Seçkin), Ankara 1995, s. 157.

32 Üstün, Teminat, s. 150; Bahçeci, s. 163; Gerçek, Teminat, s. 49; Gülseven, Mustafa: Açıklamalı- İçtihatlı Amme Alacaklarının Tahsil Usulü Hakkında Kanun, (Seçkin), Ankara 1999, s. 79; Şentürk, s. 22. Danıştay 13. D. E.1978/3931, K. 1979/1873 için bknz. Ünlü, s. 158. 
teminat isteme nedeninin varlığ 1 ve teminata esas alınacak tutar belirlemesi ihtiva eden bilgilendirme yapılarak, vergi incelemesi yapmaya yetkili kişilerin teminat istemine yönelik talepte bulunması gereklidir.

Teminat isteminin diğer bir koşulu 6183 sayılı Kanun m.9/1'de ifade edilen kamu alacağının salınmasına yönelik gerekli işlemlere başlanılmış olunmasıdır. Gerekli işlemlerin ne olduğunu incelemek gerekir. Burada gerekli işlem vergi kaçakçılığına bağlı olarak doğacak kamu alacağı için vergi tarhına yönelmiş ön işlemlere başlanılmış olmasıdır ${ }^{33}$. Buna göre kamu alacağının tarhına yönelik vergi kaçakçılığı teşkil eden fillerle vergi ziyaı varlığını gösteren bir kamu alacağının salınması için kimi işlemlere başlanılmış olması teminat istemi için yeterli olup, alacağın tahakkuk etmesine gerek yoktur ${ }^{34}$. Diğer bir ifadeyle teminat isteme nedenine yönelik tespit yapılabilecek bir aşamaya gelinmeli, ikmalen, resen veya idarece tarh işlem süreçlerine başlanılmış olunmalıdır. Kanunda açıkça gerekli işlemlerin yapılması değil, işlemlere başlanılmış olması koşul olarak yer almaktadır.

Diğer taraftan başlanılmış işlemler nihayete erdirildiğinde tespit edilen matrah fark1 üzerinden vergi tarh edilmiş ve/veya ceza kesme işlemi tesis edilmişse artık teminat istenemeyecektir ${ }^{35}$. Vergi/ceza ihbarnamelerinin tebliğ edildiği, tarh işleminin tesis edildiği, tahakkuk ve tahsil aşamalarına geçilmiş olan veya kesinleşmiş bir kamu alacağ için teminat isteme koşulu bulunmamakta olup, teminat ile henüz tarh aşaması tamamlanmamış kamu alacaklarının korunması amaçlanmaktadır ${ }^{36}$. Buna göre teminat, henüz tahakkuk etmemiş veya vadesi gelmemiş ya da cebri takip ve tahsil süreci başlanmamış, hakkında ödeme emri düzenlenmemiş kamu alacaklarına yönelik bir önlemdir ${ }^{37}$. Diğer taraftan teminattan beklenen hukuki korumaya

33 Bknz Karakoç, Kamu İcra, s. 113; Çelik, Kamu Alacakları, s. 42; Üstün, Teminat, s. 148; Gerçek, Kamu Alacakları, s. 163; Arslaner, s. 148.

34 Bknz. Candan, s. 85. Danıştay 3.D. T.13.2.2019, E.2015/12433, K.2019/982; Danıştay 4.D. T.12.1.2017, E.2016/15686, K.2017/287. (www.kazanc1.com).

35 Candan, s. 86.

36 Kızılot/Kızılot, s. 480; Coşkun, s. 126.

37 Danıştay 9.D. T.16.06.2014, E.2011/3737, K.2014/4258: “... 6183 sayılı Kanunun kamu alacağının korunması ile ilgili hükümlerini kapsayan Birinci Kısmın İkinci Bölümünde yer alan teminat istenilmesi, ihtiyati haciz e ihtiyati tahakkuk müesseseleri, henüz kamu alacağı niteliği kazanmamış vergi ve cezaların, tahakkuk ettikleri tarihte karşılaşılabilecek tahsil imkansızlığına bir önlem olarak öngörülmüştür. Dolayısıyla özel kanunlara göre henüz tahakkuk etmemiş vergi ve cezalar hakkında, kamu alacağının güvenceye bağlanması amacıyla öngörülen teminat isteme, ihtiyati haciz ve ihtiyati tahakkuk kararları alınarak uygulanması mümkündür. Tarh ve tebliğ üzerine dava konusu edilmekle tahsili duran vergi ve cezalar hakkında bu yola başvurulması Kanun hükümlerine uygun 
ihtiyaç duyulmayan bu aşamalarda diğer hukuki yolları işletmek kamu alacaklısı için daha çok hukuki menfaat taşımaktadır.

Teminat istemine yönelik diğer bir düzenleme olan 6183 sayılı Kanun m.9/2 kendi içinde farklı koşulları barındırmaktadır. Buna göre; kamu borçlusunun Türkiye'de ikametgâhı bulunmuyorsa ve bu hal kamu alacağının tahsilini tehlikede olduğunu gösteriyorsa teminat istenebilmektedir. Kanunda yer alan gerçek kişileri ilgilendiren ikametgâh kavramı yerine tüzel kişileri de kapsayacak nitelikte mali ikametgâh kavramının kullanılmasının daha isabetli olabileceğine yönelik eleştiriler bulunmaktadır ${ }^{38}$.

Bu düzenleme çerçevesinde kamu borçlusunun Türkiye'de ikametgâhın bulunmaması tek başına teminat isteme nedeni olamamaktadır. Kamu alacaklısı Türkiye'de ikametgâhı bulunmayan bir kamu borçlusunun, alacağın tahsilini tehlikeye attığını düşünüyorsa teminat isteyebilecektir. 6183 sayılı Kanun m.9/1'den farklı olan bu hüküm doğrudan kamu borçlusunu muhatap almıştır. Bu haliyle bu maddeye dayalı olarak teminat isteyebilmek için kişinin kamu borçlusu sıfatı taşıor olması gereklidir. Ayrıca kamu borçlusunun Türkiye'de ikametgâhının bulunmayışı ile kamu alacağının tahsil tehlikesi birlikte var olmalı ve her iki koşul arasında bağ kurulmalıdır.

Her olayın kendi koşulları içinde somutlaştırılacağı bu konuda kamu alacaklısının geniş bir değerlendirme yelpazesi ve takdir yetkisi bulunmaktadır. Ancak 6183 sayılı Kanun m.9/1'den farklı olarak, kamu alacağının tahsil tehlikesinde olduğu hususunun burada ayrıca araştırılması ve tespiti zaruri bir koşul olarak belirlendiği unutulmamalıdır. Bu halde keyfi olmayan usule ve somut gerekçelere dayalı olarak bu koşul ortaya konulmalıdır. Kamu alacağının tahsilinin tehlikede olduğunu gösteren emarelere örnek olarak borçlunun işlerini tasfiye etmesi, yurt dışına yerleşmesi, banka hareketlilikleri vb. gibi dayanaklar gösterilebilmektedir ${ }^{39}$. Ayrıca borçlunun aktifinde kayıtlı menkul ve gayrimenkulleri başkaları adına tescil ettirmesi, mal kaçırmaya yönelik muvazaalı hareketlerde bulunması, finansman sağlayarak bazı varlıkları üçüncü kişilere aldırması, değeri altında satış yapması, yurt dışına nakit transferi, işlerinin bozulmaya başlaması gibi örnekleri çoğaltmak

bulunmamaktadır." (www.legalbank.net); Danıştay 7.D. T.3.10.2007, E.2006/1290, K.2007/3914: "Ödeme emri aşaması da geçirilen kamu alacağının tahsili için 6183 sayılı Kanunda öngörülen diğer cebren tahsil yöntemlerine başvurulması gerekirken, teminat istenmesi yolunda tesis edilen işlem de yasaya uyarlık bulunmamaktadır." (www.kazanc1.com).

38 Bayraklı, s. 34.

39 Candan, s. 87; Çelik, Kamu Alacakları, s. 44; Üstün, Teminat, s. 149; Gerçek, Kamu Alacakları, s. 164; Taylar, s. 74. 
mümkündür ${ }^{40}$. Diğer taraftan koşulları bulunmasına rağmen bu hükme dayalı olarak teminat isteyip, istememenin idarenin takdirinde olduğunu yinelemek gerekir.

\section{Teminat İsteme Yetkisi}

Koşulları oluştuktan sonra teminat isteme yetkisi alacaklı kamu idaresinin tahsil dairesine aittir. 6183 sayılı Kanunda yer alan hükümleri yerine getirmekle görevli tahsil dairesi devlete ait kamu alacakları için yetkilendirilmiş vergi idaresi, il özel idaresi ve belediyelere ait kamu alacakları için kendi tahsil daireleridir. Alacaklı tahsil dairesini ilgili mevzuat gereği görevlendirilmiş birim, servis, memur veya memurlar olarak ele almak gerekir ${ }^{41}$.

6183 sayılı Kanun m.9/1'e göre teminat istemine dair Kanun hükümlerinin uygulanabilmesi bir vergi incelemesine ihtiyaç duyulmakta, teminat isteme yetkisinin doğması için öncelikle bir vergi incelemesinin bulunması gerekmektedir. Kamu borçlusundan teminat isteyen ve bu doğrultuda tebliğ gerçekleştiren alacaklı tahsil dairesi olmasına rağmen tahsil dairesi teminat isteme koşullarının varlığını, vergi incelemeye yetkili memurlar vasıtasıyla öğrenmektedir.

Vergi incelemesi sırasında vergi incelemeye yetkili kişilerce teminat isteme nedenlerinin oluştuğu tespiti ve yapılan ilk hesaplamalara göre belirlenen tutarı ihtiva eden talep içerikli gerekçeli ön rapor veya yazı hazırlanarak tahsil dairesine iletilmektedir ${ }^{42}$. Teminat isteme vergi incelemesi ile başlayıp vergi incelemesi ile son bulan bir görünüm arz etse de burada asıl olan tarhiyat öncesi bu yetkinin kullanılmış olmasıdır. Bu nedenle bilgilendirme ve talep vergi inceleme sırasında gerekçeli olarak düzenlenecek bir yazı ile tahsil dairesine sunulabileceği gibi vergi inceleme raporuyla da iletilebilecektir. Diğer bir deyişle vergi incelemeye yetkili memurlar, vergi inceleme sırasında tahsil dairesine gerekçeli bir ön rapor sunarak teminat

\footnotetext{
40 Koçak, s. 112.

41 Candan, s. 87; Yapar, s. 98. Vergi alacakları için yetkili tahsil dairesinin vergi dairesi başkanlıkları ile vergilendirme grup müdürlükleri olduğu yönündeki görüşleri için bknz. Baysal, s. 1165-1167; Şentürk, s. 5.

42 Bayraklı, s. 35; Kızılot/Kızılot, s. 480; Gerçek, Kamu Alacakları, s. 163; Bahçeci, s. 163; Arslaner, s. 148; Koçak, s. 110; Yapar, s. 99; Şentürk, s. 17. Uygulamada gerekçeli bir ön rapor yerine birkaç satırlık gerekçesiz bir yazı ile yetinilebildiği ve bunun keyfiliğe ve kamu yararına uygun olmayan başka amaçlarla hareket edilmesine neden olabileceği için son derece sakıncalı olduğu yönündeki görüşleri için bknz. Doğrusöz, https://www.dunya.com/kose-yazisi/vergi-dairesinin-teminat-talebi/23939. (20.02.2020).
} 
isteme nedenini ve tutar belirlemesini ihtiva eden bilgi ve talebi iletebileceği gibi vergi inceleme raporuna ilave edeceği bir bölümle de bunu yapabilecektir.

Vergi incelemesi sonuçlanıp vergi ve/veya ceza ihbarnameleri kamu borçlusuna tebliğ edilerek, tarhiyat yapıldıktan sonra teminat istenemeyecektir $^{43}$. Vergi incelemesi bittikten sonra uygulamada teminat istemine başvurulduğu, Danıştay'ın inceleme tamamlanıp tarhiyat yapıldıktan sonra teminat istemenin hukuka aykırı olacağı yönünde kararlar verdiği bilinmektedir ${ }^{44}$. Ancak burada dikkat edilecek husus vergi inceleme raporunun vergi idaresine ulaşması ile tesis edilen tarh işlemi ve tahakkuk aşaması arasında bir zaman diliminin bulunmasıdır. Diğer bir ifadeyle vergi incelemesi tamamlandığında ve vergi inceleme raporu vergi idaresine gönderildiğinde doğrudan tarh işlemi gerçekleşmiş olmamakta ve tahakkuk aşamasına gelinmemektedir.

$\mathrm{Bu}$ halde vurgulanması gereken tarh işlemi tesis edildiğinde artık teminat istenemeyecek oluşudur. Ancak vergi incelemesinin bitirilmiş olması tek başına teminat isteme koşulunu ortadan kaldırmamaktadır. Vergi incelemesi tamamlandığında öncesinde hazırlanmış olan vergi inceleme raporunda

43 Gerçek, Teminat, s. 48. Danıştay 9.D. T.17.12.2013, E.2010/7036, K.2013/12263: “... Ancak vergi incelemesinin devam ettiği durumlarda yapılan ilk hesaplamalara göre teminat istenebilecek ve ihtiyati haciz kararı alınabilecektir. İnceleme sonuçlanıp, tarhiyat yapıldıktan sonra bu düzenleme uyarınca teminat istenmesi söz konusu olmayacaktır. Diğer bir deyimle, 9. Madde uyarınca ilgilerden teminat istenebilmesi için incelemenin henüz tamamlanmamış olması gerekir." (www.legalbank.net); Danıştay 3.D. T.09.02.2015, E.2011/3698, K.2015/547: “ ... inceleme sonuçlanıp tarhiyatlar yapıldıktan sonra teminat istenilmesine olanak bulunmadığı, öte yandan, Türkiye'de ikametgahı bulunan mükelleflerden vergi inceleme elemanının talebi bulunmadan kendiliğinden teminat istenemeyeceği, olayda vergi inceleme elemanın önerisi olmaksızın incelemenin sonuçlanması ve tarhiyatların tebliğinden sonra tesis edilen teminat istenmesine ilişkin işlemde hukuka uygunluk görülmediği ..." (www.legalbank.net); Danıştay 9.D. T.23.06.2009, E.2008/669, K.2009/2781: “... Buna göre, ancak vergi incelemesinin devam ettiği durumlarda yapılan ilk hesaplamalara göre teminat istenebilecek ve ihtiyati haciz kararı alınabilecektir. İnceleme sonuçlanıp, tarhiyat yapıldıktan sonra bu düzenleme uyarınca ihtiyati haciz kararı alınması söz konusu olmayacaktır. Diğer bir deyimle, 9. madde uyarınca ilgililer hakkında ihtiyati haciz kararı alınabilmesi ve teminat istenebilmesi için incelemenin henüz tamamlanmamış olması gerekmektedir." Bu doğrultudaki başka bir karar Danıştay 9. D. T.23.06.2009, E.2008/12, K.2009/2782. (www.kazanc1.com).

44 Bknz. Alpaslan, Mustafa/Şentürk, Akın Gencer: "Vergi İncelemelerinde İhtiyati Haciz İhtiyati Tahakkuk Sonucunda Teminat Talep Edilebilmesi İçin VUK 344 ve 359 Maddelerinin Mevcudiyeti Topluca Gereklidir", Legal Mali Hukuk Dergisi, Sayı:53, 2009, s. 924; Arslan, s. 2475. 
yer almış tutar belirlemesi ve talep tarh işlemi gerçekleştirilene kadar alacaklı tahsil dairesi için geçerli teminat isteme halini oluşturabilmektedir. Diğer taraftan vergi inceleme raporunda böyle bir halin yer almaması durumunda inceleme tamamlandiktan sonra farklı bir hukuki yol ile teminat isteminin tahsil dairesine ulaştırılması mümkün olmayacaktır.

Vergi incelemesi sirasında vergi incelemeye yetkili memurun teminat isteme nedenine ilişkin olayın gerçekte vuku bulmuş olduğu kanaatine mutlak surette ulaştı̆̆ını beklemek olanaksızdır. Teminat, özü ve amacıyla tahsil tehlikesi ihtimali üzerine inşa edilen hukuki bir kurumdur. Henüz tarh aşaması bile tamamlanmamış bir sürecin başında kamu alacağının esasına dair VUK, m.359'da yazılı fiillerle vergi ziyaı cezası gerektiren bir kamu alacağının oluştuğunu tespit etmek mümkün değildir. Bu nedenle vergi inceleme elemanından bu aşamada fiil ve/veya manevi unsur tespiti yaparak VUK, m.359'a dayalı bir vergi ziyaı oluştuğuna karar vermesi beklenemez. Kanun koyucunun bu gerçeğin farkında olarak 6183 sayılı Kanunda teminat kurumunu düzenlemiş olduğu düşünülmektedir. Zira 6183 sayılı Kanunda teminat isteme nedeni VUK, m.359'da yazılı fillerin işlenmiş olması değil VUK, m.359'de sayılan hallere temas eden bir kamu alacağı için gerekli işlemelere başlanılmış olmasıdır. Temas eden ifadesi ispat ölçütüne yönelik belirsiz bir alan açmakla beraber ${ }^{45}$, bu düzenleme teminat isteme nedeninin kesinleşmiş olgulara dayandırılmasının zorunlu olmadığını göstermektedir.

Diğer taraftan teminat istemi nedeni olduğunu iddia edebilmek ve hesaplama yapabilmek için gerekçeli ön rapor hazırlayabilecek düzeyde bilgi ve kanaat sahibi olunması gerektiği bir hakikattir. Diğer bir deyişle vergi incelemeye yetkili olan memur kayıt ve belgeler üzerinden gerçek anlamda bir inceleme yapmalı, teminat isteme talebini ve hesaplamasını somut bilgi ve emarelere dayandırmalidır.

Danıştay verdiği bir kararda defter ve belgelerin incelemeye ibraz edilmesi için verilen süre dolmadan teminat istenmesinin hukuka aykırı olduğuna hükmetmiştir ${ }^{46}$. Açıktır ki henüz defter ve belgeler incelenmeden teminat isteme nedeninin var olduğu tespit edilemeyeceği gibi, teminata esas

Bknz. Yapar, s. 93-94; Şentürk, s. 19.

Danıştay 9.D. T.4.11.2004, E.2002/358, K.2004/5373: “... bu durumda, 6183 say1lı Kanunun 9. maddesinde belirtilen amme alacağının tahsili ve teminat istenilebilmesi için gerekli işlemlere başlanması ve incelemeye yetkili memurlarca ilk hesaplara göre bir miktarın belirtilmesi şartı oluşmadan teminat istenilmesi ve anılan Kanunun 13. maddesinde sayllan ihtiyaten haczi gerektiren sebeplerden birinin varlığ hususunda somut tespitler ortaya konulmadan, soyut ve varsayıma dayalı iddialarla uygulanan haciz işleminde ve teminat istenilmesinde isabet görülmediği..." (www.kazancı.com). 
alınacak tutar belirlemesi de yapılamayacaktır. Dolayısıyla vergi incelemeye yetkili memurlarca keyfiliğe yol açmayan bir surette kullanılacak yetki çerçevesinde teminat isteme nedenine yönelik varsayımsal ve soyut olmayan bir şüphe bulunmalıdır.

Vergi incelemeye yetkili memurlarca teminat isteme nedeninin oluştuğu ve ilk hesaplara göre belirlenen miktar tespitiyle tahsil dairesine ulaşan bilgi ve talep sonrası, tahsil dairesi tarafından teminat istemi gerçekleştirilecektir. Vergi incelemeye yetkili kişilerin tahsil dairesine bu yönde bir talep iletmesi durumunda tahsil dairesinin teminat isteminde bulunmak zorunda olduğu doğrultusunda bir görüş bulunmaktadır ${ }^{47}$. Ancak kamu alacaklarının korunmasına yönelik olağan dışı bir önlem ve aynı zamanda idari bir işlem olan teminat isteme yetkisinin denetim elemanlarının yer aldığı vergi incelemesi yapmaya yetkili olanlara bırakılması anlamı ihtiva edebilecek böyle bir yaklaşım, vergi idaresinin yapısına ve 6183 sayılı Kanun sistematiğine uygun değildir.

Vergi incelemeye yetkili kişilerin teminat isteme nedeninin varlığ ve teminata esas alınacak tutarı iletmek ile teminat talep etmekle sınırlı yetkisi bulunmaktadır. Teminat isteme koşullarının varlığı konusunda nihai karar verme yetkisi alacaklı tahsil dairesine aittir. Teminat nedeninin ve yapılan ilk hesaplamanın tahsil dairesine ulaştırılması ve böylece talepte bulunulması teminat isteme işleminin hazırlık sürecidir. Bu halde vergi incelemeye yetkili memurun tutar belirleyerek teminat isteme talebi, icrai nitelikte olmayan hazırlık işlemidir ${ }^{48}$. Teminat isteme işlemi öncesi aşılması gereken bir aşamayı oluşturan bu işlem karar alan makamı bağlamamaktadır. Bu niteliğinden dolayı teminat isteme öncesi gerçekleşen bu işlemlere karşı doğrudan dava açılamayacaktır. Hazırlayıcı işlemdeki hukuka aykırılık halleri, bu işleme dayanılarak yapılmış olan asıl teminat isteme yazısına karşı ileri sürülebilecektir.

Diğer taraftan bu aşama ve talep olmaksızın tahsil dairesinin kendiliğinden teminat isteme kararı veremeyeceği, inceleme elemanının hesaplaması ve talebinin şart olduğunu ifade etmek gerekir ${ }^{49}$. Diğer bir deyişle

47 Gerçek, Kamu Alacakları, s. 53; Arslaner, s. 148; Gerçek, Teminat, s. 53-54; Baysal, s. 1168; Şeker, s. 162; Doğrusöz, https://www.dunya.com/kose-yazisi/vergi-dairesininteminat-talebi/23939. (20.02.2020).

48 Hazırlık işlemleri için bknz. Gözler, Kemal/Kaplan, Gürsel: İdare Hukuku Dersleri, Güncellenmiş 21. Bask1, (Ekin), Bursa 2019, s. 269-273.

49 Kızılot/Kızılot, s. 480; Gerçek, Teminat, s. 48. Danıştay 3.D. T.9.2.2015, E.2011/3698, K.2015/547: "Teminat, ancak vergi incelemesinin devam ettiği durumlarda yapılan ilk hesaplamalara göre istenebilecek tarhiyatlara hazırlayıcı mahiyette ve alacağın korun- 
alacaklı tahsil dairesi bu hazırlık süreci olmadan haricen elde edeceği bilgiler üzerinden veya vergi inceleme raporunda yer alan açıklamalardan kendi varacağı çıkarımlar yoluyla kendiliğinden teminat isteme işlemi uygulayamayacaktır.

Ancak bu noktada vergi incelemeye yetkili memurların taleplerinin bağlayıcı olmadığını vurgulamak gerekir ${ }^{50}$. Teminat isteme nedeni olan VUK, m.359'da sayılı hallerin ortaya konulabileceği vergi incelemesinde sürecin henüz başında hesaplama yaparak, teminat isteme nedenlerine ilk ulaşabilecek olan vergi incelemeye yetkili olan kişilerdir. Kanun koyucu böyle bir ihtiyaca istinaden bu kişileri alacaklı tahsil dairesine asıl işleme dayanak olan hazırlayıcı işlemi yapma yetkisi vererek alınacak kararın etkinliğini artırmayı amaçlamaktadır.

Buna göre vergi incelemeye yetkili memurun ilk hesaplamalara göre belirlediği tutarı esas alarak teminat isteme koşullarının var olup olmadığına dair nihai kararı verecek olan yetki sahibi Kanunda açıkça ifade edildiği üzere alacaklı tahsil daireleridir. 6183 sayılı Kanun m.9/1'de yer alan koşulların oluşumu halinde ise kamu alacaklısının teminat isteme yoluna başvurmas1 zorunludur ${ }^{51}$. Kanun burada idareye bağlı yetki vererek alternatif bir seçim şansı tanımamaktadır. Bu haliyle bu yetki idare için aynı zamanda bir sorumluluk teşkil etmektedir.

Diğer taraftan 6183 say1lı Kanun m.9/2'de yer alan teminat isteme koşulları doğrudan tahsil dairesi tarafından ele alınmaktadır. Burada öncesi bir vergi incelemesine ihtiyaç duyulmadığı gibi, vergi incelemeye yetkili kişilerin hesaplama yapmasına veya talepte bulunmasına da gerek yoktur. Tahsil dairesi koşulların varlığını tespit ettiği halde takdirine bağlı olarak kamu borçlusundan teminat isteyebilecektir.

masına yönelik tedbir olup, inceleme sonuçlanıp tarhiyatlar yapıldıktan sonra teminat istenilmesine olanak bulunmamaktadır. Türkiye'de ikametgâhı bulunan mükelleflerden vergi inceleme elemanının talebi bulunmadan kendiliğinden teminat istenemez". (www.kazancı.com) Danıştay 9.D. T. 28.01.2009, E.2008/761, K.2009/236: "Kaçakçılık suçu sayılan fiiller nedeniyle hesaplanan vergi ve ceza üzerinden teminat, ancak vergi inceleme elemanınca yapılan ilk hesaplara göre belirtilen miktar üzerinden istenebileceği; vergi inceleme elemanı tarafindan teminat istenmesi yolunda herhangi bir talep olmadığı halde idare tarafından kendiliğinden tesis edilen teminat isteme işleminin hukuka aykırı olduğu" (www.legalbank.net).

50 Barlass'a göre vergi inceleme elemanını görevlendiren idare görevlendirdiği kişinin yaptığı çalışmanın ilk sonuçlarını kendisiyle paylaşmasını talep edebilir. Vergi inceleme elemanı vergi idaresini temsilen görev ifa etiğinden vergi idaresinin teminat isteme yetkisini ortadan kaldıran bir düzenleme yoktur. Bknz. Barlass, s. 16-17.

51

Taşkan, s. 307; Coșkun, s. 128. 


\section{Teminat İsteme Usulü}

Teminat isteme usulü içerisinde teminatın kimden, hangi tutarda ve nasıl istenilebileceği ele alınmalıdır. 6183 sayılı Kanun m.9 çerçevesinde teminat isteminin muhatabı kamu borçlusu olmalıdır. Kamu borçlusu olarak kabul edilebilen; mirası ret etmemiş mirasçılar, işi devralanlar, kanuni temsilciler, kefiller veya limited şirket ortaklarından da teminat istenebilmektedir $^{52}$. Diğer taraftan m.9/1 kapsamında yapılacak teminat isteminin tahakkuk etmemiş ve/veya kesinleşmemiş alacaklar olduğu düşünüldügünde henüz kamu borçlusu sıfatı taşımayan ve belki de hiç taşımayacak olan kişilerden de teminat istenebileceği bir gerçektir. 6183 sayılı Kanun m.9/2'de ise doğrudan kamu borçlusu sıfatına haiz gerçek veya tüzel kişiler hedef tutulmuştur.

Teminat tutarının nasıl hesaplanacağ ifade edilmemiştir. 6183 sayılı Kanun m.9/1'de vergi incelemeye yetkili olan kişilerce ilk hesaplamalara göre belirlenen miktarın teminat tutarı olacağı hükmedilmiştir. $\mathrm{Bu}$ fikra düzenlemesine dayalı teminat isteminde teminat gösterilecek olan değer, vergi incelemesi yapan memurun hesapladığı miktar kadar olmalıdır. Burada dikkat edilecek konu teminata esas alınacak miktarın yükümlendirilecek kamu alacağıyla ölçülü olması gerekliliğidir.

Diğer taraftan Tahsilat Genel Tebliğinde vergi incelemesine yetkili memurlarca yapılan ilk hesaplamalara göre belirtilen tutar üzerinden istenecek teminatın, vergi aslı, gecikme faizi ile diğer ceza tutarlarını karşılayacak değerde olması gerekliliğine işaret edilmektedir. Vergi alacağı tahakkuk edemediğinden gecikme faizinin hesabında teminat isteme yazısının düzenlendiği tarih esas alınacaktır. Ayrıca gerek teminat isteme yazılarında gerekse teminat gösterme yazıları veya belgelerinde, vergi alacağının tahakkuk etmesi üzerine hesaplanacak gecikme faizi ve zammın dikkate alınacağının belirtileceği ifade edilmiştir. Bu doğrultuda Tahsilat Genel Tebliğinde yer alan teminat isteme yazısı örneği olan EK-1 içeriğinde, bu yazıda ihtiva olunacak unsurlarla birlikte tutarın yer aldığı bölümde vergi aslı, vergi ziyaı cezası ve gecikme faizi için ayrılmış boşluklar bulunmaktadır. Diğer taraftan bu yazıda, gösterilen teminatın kamu alacağının tahakkuk ve tahsil tarihine göre hesaplanacak gecikme faizi ve gecikme zammı için de paraya çevrilebileceği uyarısı yer almaktadır.

6183 say1lı Kanun m.9/2 kapsamında bulunan teminat istemi konusunda ise ayrıca bir açıklama yoktur. Bu noktada kamu borçlusunun 52 Bayraklı, s. 35; Çelik, Kamu Alacakları, s. 40; Şimşek, s. 82; Coşkun, s. 126; Kaneti/
Ekmekçi/Güneş/Kaşıķ̧ı, s. 572. 
Türkiye'de ikametgâhı olmaması ve bu durumun kamu alacağının tahsilini tehlikeye düşürmesi sebebiyle teminat istenmesi hallerinde teminat tutarının kamu alacağını karşılayabilecek yeterlilikte olmasına dikkat edilmelidir.

Teminat istenmesindeki şekil konusu Kanunda ifade edilmemiştir. Ancak uygulamada teminat isteminin yazılı yapılması gereği kabul edilmektedir $^{53}$. Tahsilat Genel Tebliği EK,1'de yer alan evrak doldurulup, gönderilmek suretiyle teminat istenmektedir.

Teminat istemi yazısı kamu borçlusuna gönderildiğinde teminatın gösterilmesi için kendisine bir süre tanınıp, tanınmayacağı Kanunda ifade edilmemiştir. Ancak Tahsilat Genel Tebliğinde 6183 sayılı Kanun m.8 ile tebliğlerin yapılması ve sürelerin hesaplanması bakımından 213 sayılı Kanuna atıf yapıldığg ve bu atfın VUK m.14-18 maddelerinden ibaret üçüncü bölümün tamamına şamil olduğu gerekçesiyle, 213 sayılı Kanun m.14 hükmü çerçevesinde teminat isteme yazılarında teminat gösterilebilmesi için 15 günden az olmamak üzere süre verilmesi gerektiği açıklaması yer almaktadır. Bu açıklamaya uygun surette doktrinde yaygın görüş en az 15 günlük sürenin tanınmasına yöneliktir ${ }^{54}$. Diğger taraftan teminat gösterilmesi gereken bir halde tahsil dairesi ihtiyati hacze girişerek hiçbir süreyle kayıtlı olmaksızın ihtiyati haczi uygulayabileceğinden bu işlemi durdurabilmek için kamu borçlusunun derhal teminat göstermesi gerekeceği de bir gerçektir ${ }^{55}$. Ancak teminat müessesinin kabul amacı, ticari ve iktisadi hayat gerçekleri ve idari teamüllere istinaden, teminat istenilmesi durumunda kamu borçlusuna teminatı temin edebilmesi bakımından mutlaka bir süre verilmeli ve bu süre 15 günden az olmamalıdır ${ }^{56}$.

Kamu alacaklısının teminat isteme yazısı ile kamu borçlusunun teminat gösterme tutumu birbirinden ayrı durumlardır. Teminat isteme yazısı tahsil dairesine doğrudan teminat alma hak ve yetkisi vermemektedir. Ancak kişinin hukuki menfaatini etkileyen ve belli hukuki sonuçlara katlanmasına

53 Candan'a göre ihtiyati haciz koşullarını düzenleyen 13'üncü maddenin 4 numaralı bendi anlatımından isteğin yazıyla yapılması gerektiği anlaşılmaktadır. Bknz. Candan, a.g.e., s. 88 .

54 Kaneti/Ekmekçi/Güneş/Kaşıkçı, s. 572; Bayraklı, s. 35; Çelik, Kamu Alacakları, s. 41; Üstün, Teminat, s. 150; Gerçek, Kamu Alacakları, s. 161; Koçak, s. 108; Yapar, s. 101-102. Candan'a göre burada yer alan husus VUK, m.14 kapsamına dahil değildir. Bknz. Candan, s. 88. Aynı doğrultudaki görüşleri için bknz. Bahçeci, s. 164.

55 Karakoç, Kamu İcra, s. 117; Arslaner, s. 151. Danıştay 7.D. T.25.3.1969, E.1968/1204, K. 1969/685: “... teminat istenmesi halinde ihtiyati haczin tatbiki için, teminat gösterilip gösterilemeyeceğini beklemenin zorunlu olmadığı, aksine teminat istenmesini mucip hallerin varlığı halinde ihtiyati haczin derhal tatbik olunacağı ...” bknz. Gülseven, s. 83.

Karakoç, Genel Vergi, s. 513-514. 
neden olabilen teminat isteme yazısı kesin ve yürütülmesi zorunlu bir idari işlem olup, tek başına dava konusu edilebilmektedir ${ }^{57}$. Hakkında idari işlem tesis olunan kamu borçlusunun, işleme yönelik hareketini belirleyebilmesi için kendisine rasyonel bir süre tanınmalıdır. Burada kamu borçlusu teminat gösterme, tesis edilen işleme dava açma veya hareketsiz kalma tercihlerini kullanarak seçiminin hukuki sonuçlarını takip edecektir. Bu haliyle ihtiyati haczin uygulanıp, uygulanmamasından tamamen bağımsız bir şekilde, teminat isteme yazına karşı kamu borçlusuna uygun bir süre verilmesi yerinde bir yaklaşım olacaktır.

\section{TEMINAT OLARAK KABUL EDILEN DEĞERLER}

\section{A. Genel Olarak}

Teminat isteme sürecinde kamu alacaklısı teminat isteme ve gösterilen teminatı kabul etme şeklinde iki ayrı idari yetki kullanabilmektedir ${ }^{58}$. Bu haliyle teminat olarak gösterilen her türlü kıymetin kamu alacaklısı tarafindan kabul edilmesi zorunlu değildir ${ }^{59} .6183$ sayılı Kanunda teminat olarak kabul edilecek değerler belirlenmiştir. Buna göre teminat gösterme tutumunun konusu olabilecek nakdi ve ayni unsurlar Kanun tarafindan sınırlandirılarak bir taraftan kamu alacaklısına her türlü kıymeti kabul etmeme yetkisi tanınırken diğer taraftan teminat gösterene Kanunda yer alan değerlerin teminat olarak kabul edileceği güvencesi verilmektedir.

6183 sayılı Kanun m.10 hükmü tahsil dairesinin teminat olarak kabul edeceği değerleri, m.11 bu değerlerin teminat sağlamaya yetmemesi durumunda şahsi teminat gösterilebileceğine yönelik hükmü, m.12 ise Kanunen teminat hükmünde kabul edilen eşyaları düzenlemektedir. Teminat olarak kabul edilebilecek değerleri maddi ve şahsi teminat olmak üzere iki grupta incelemek mümkündür.

\section{B. Maddi Teminat}

6183 sayılı Kanunda maddi teminat teşkil edebilecek değerlere yönelik m.10 düzenlemesini ele almak gerekir. Bu hükümde sayılı olan değerler devlet güvencesinde olan ve değer aşınmasına karşı korumalı olduğu düşünülen unsurlardır ${ }^{60}$. Kanun koyucu burada sınırlandırıcı bir yaklaşım sergi-

\footnotetext{
57 Candan, s. 89; Gerçek, Kamu Alacakları, s. 161; Arslaner, s. 151; Yapar, s. 101.

58 Bahçeci, s. 158.

59 Candan, s. 90.

60 Gerçek, Kamu Alacakları, s. 165.
} 
lemiş ve her şeyin teminat olarak gösterilebilmesine izin vermemiştir. Özellikle haciz veya ihtiyati hacze konu olabilecek değerlerin daha geniş olabildiği değerlendirildiğinde buradaki kısıtlamaya yönelik eleştiriler bulunmaktadır ${ }^{61}$. Ancak diğer taraftan kamu alacaklısının Kanunda yer alan değerleri teminat olarak kabul etmek zorunda olduğu düşünüldüğünde bu düzenlemenin borçluyu koruyan bir yönü de vardır.

6183 sayılı Kanun m.10'da belirlenmiş olan maddi değerler şunlardır:

Para: Tedavülde olan madeni ve kâğıt paralar, teminat olarak gösterilebilecek en önemli değerlerdir. Kanunda Türk parasının kastedildiğine yönelik bir görüş bulunmaktadır ${ }^{62}$. Ancak yabancı paraların (döviz) teminat olarak gösterilebilmesine herhangi bir kanuni engel bulunmadığından yabancı paraları da teminat olarak kabul etmek gerekir ${ }^{63}$.

Bankalar ve özel finans kurumları tarafindan verilen teminat mektupları: Teminat mektupları belirsizliğin ve güvensizliğin ürünü olup, ekonominin gelişmesi, mal ve hizmet hareketlerinin artmasıla mali durumu ve güvenirliği konusunda fazla bilgi sahibi olunmayan kişilerle kurulmak durumunda olan ticari ilişkilerde, karşı edimde ifadesini bulan ekonomik çıkarın mutlaka elde edileceği güvencesini sağlamak için verilen bir değer$\operatorname{dir}^{64}$. İş sahiplerinin üstlendikleri yükümlülükleri yerine getireceği taahhüdüyle bankalar veya özel kurumlar tarafindan iş sahipleri lehine bu kişiler veya kurumlara hitaben verilmektedir ${ }^{65}$. Türk hukukunda teminat mektuplarının hukuki niteliğinin, özel olarak bu biçimde düzenlenmiş bulunanlar hariç kefalet değil, garanti olduğu kabul edilmektedir ${ }^{66}$.

5411 sayılı Bankacılık Kanunu m.3'e göre banka; mevduat bankaları ve katılım bankaları ile kalkınma ve yatırım bankalarını ifade eder. 5411 sayılı Kanun m.169 hükmünde; “... Diğer kanunlarda ve mülga 3182 sayılı Bankalar Kanunu ve bu Kanunla yürürlükten kaldırılan 4389 sayılı Bankalar Kanununda özel finans kurumlarına yapılan atıflar, katılım bankalarına

61 Bknz. Arslaner, s. 150; Yapar, s. 101.

62 Candan, s. 90. Tartışma için bknz. Yapar, s. 103-104.

63 Çelik, Kamu Alacakları, s. 47; Üstün, Teminat, s. 151. Yabancı paranın teminat gösterilmesi durumunda bunların o gün için TC. Merkez Bankası tarafindan belirlenen döviz kuruna göre değerlenerek kabul edilmesi gerekeceği yönündeki görüşleri için bknz. Gerçek, Teminat, s. 27-28.

64 Arkan, Sabih: "Teminat Mektubu Veren Bankanın Hukuki Durumu”, Banka ve Ticaret Hukuku Dergisi, Cilt:16, Sayı:4, 1992, s. 59.

65 Çelik, Kamu Alacakları, s. 48; Gerçek, Kamu Alacakları, s. 166.

66

Arkan, s. 60. 
yapılmış sayılıı" ifadeleri yer almaktadır. Bu haliyle 01.01.2005 tarihli 5234 sayılı Kanunla ilave edilen özel finans kurumları olarak faaliyet sürdüren kurumlar halihazırdaki mevzuata göre katılım bankası olarak isimlendirilip bu niteliği haiz olduklarından, 6183 sayılı Kanunda ifade edilen özel finans kurumlarını katılım bankaları olarak anlamak gerekir.

Teminat mektupları, süreli veya süresiz verilebiliyor olmakla beraber burada sadece süresiz ve koşulsuz teminatlar kabul edilmektedir. Ayrıca bu mektuplar nominal değeri üzerinden teminat olmaktadır ${ }^{67}$.

6183 sayılı Kanunun bu hükmü gereğince bankalar tarafindan verilen süresiz nitelikteki teminat mektupları, üçüncü kişinin fiilini taahhüt niteliğinde garanti sözleşmesidir. Burada garanti veren banka, kamu alacaklısı karşısında bağımsız bir yükümlülük altına girmekte, kamu borçlusuna yönelik riskleri üzerine alarak, tahsil güvencesi sunmaktadır.

Hazine Müsteşarlığınca ihraç edilen Devlet iç borçlanma senetleri veya bu senetler yerine düzenlenen belgeler (nominal bedele faiz dahil edilerek ihraç edilmiş ise bu işlemlerde anaparaya tekabül eden satış değerleri esas alınır.): 4749 sayılı Kamu Finansmanı ve Borç Yönetiminin Düzenlenmesi Hakkında Kanun m.3'e göre devlet iç borçlanma senetleri; Hazine Müsteşarllğı tarafından yurt içinde ihraç edilen borçlanma senetleridir. Aynı Kanunda devlet tahvili, ihraç edildiği tarih itibarıla bir yıl (364 gün) ve daha uzun vadeli olan iç borç senedi, hazine bonosu ise ihraç edildiği tarih itibarıyla vadeleri bir yıldan kısa olan (364 güne kadar) devlet iç borçlanma senedi olarak tarif edilmektedir. Devletin iç borcunun bir bileşenini oluşturan nakit ve özel tertip iç borçlanma senetlerini de bu kapsamda teminat olarak kabul etmek gerekir.

Ayrica Kanun bu senetler yerine düzenlenen belgelerin de teminat olabileceğini belirlemektedir. Devlet iç borçlanma senetleri günlük değeriyle, günlük değeri yoksa borsa değeriyle, borsa değeri yoksa kayıtlı değerine gün esasına göre işleyen faiz ilave edilerek değerlenecektir ${ }^{68}$. Diğer taraftan nominal bedele faiz dahil edilerek ihraç edilmişse, teminat işlemine anaparaya karşılık gelen satış değeri esas alınmalıdır. Bir başka ifadeyle faiz karş1lığı gelen değer teminat miktarına dahil edilmeyecektir ${ }^{69}$.

Hükümetçe belli edilecek Milli esham ve tahvilat "Bu esham ve tahvilat, teminatın kabul edilmesine en yakın borsa cetvelleri üzerinden

Gerçek, Teminat, s. 30; Coşkun, s. 144; Koçak, s. 115.

Gerçek, Kamu Alacakları, s. 166.

Çelik, Kamu Alacakları, s. 49; Gerçek, Kamu Alacakları s. 167; Coşkun, s. 144. 
\%15 noksanıyla değerlendirilir.": Esham ve tahvilat kavramları, hisse senedi ve tahvilin şu an itibariyle yaygın kullanılmayan karşılıklarıdır. 6183 sayılı Kanunda yer alan hükümet ifadesini ise 6771 sayılı Kanun çerçevesinde Cumhurbaşkanı olarak anlamak gerekir. Bu kapsamda Cumhurbaşkanı tarafindan belirlenecek hisse senetleri ve tahviller teminat olabilecektir. $\mathrm{Bu}$ hisse senedi ve tahvillerin özel şirkete ait ve borsada işlem görmesinin gerekli olduğu ve belirlenen bu hisse senetleri ve tahvillerin hangi şirketlere ait olduğu ve ne şekilde kabul edileceklerinin Hazine ve Maliye Bakanlığı tarafindan genelgelerle teşkilata duyurulduğu ifade edilmektedir ${ }^{70}$.

Diğer taraftan uygulanma kabiliyeti açısından işlevsel olmayan bu düzenleme yerine ülkemizdeki sermaye piyasasının gelişimine uygun surette belirli ölçütler saptanarak, bu piyasalarda işlem gören ve ölçütlere uyan hisse senetlerinin teminat olarak kabul edilmesi daha faydalı olabilecektir ${ }^{71}$.

6183 sayılı Kanunda söz konusu hisse senetleri ve tahvillerin en yakın borsa cetvelinde yazılı değerinin yüzde 15 noksanı ile değerleneceği hüküm altına alınarak, olası piyasa dalgalanmalarına karşı koruyucu bir önlem alınmıştır.

İlgililer veya ilgililer lehine üçüncü şahsılar tarafından gösterilen ve alacaklı amme idarelerince haciz varakalarına müsteniden haczedilen menkul ve gayrimenkul mallar: Menkul ve gayrimenkul malların teminat olarak gösterilmesi kabul edilebilmektedir. Ancak bu eşyaların teminat olarak kabulü için teminat gösterilen bu mallar üzerinde haciz varakalarına dayanılarak haciz konulmalıdır ${ }^{72}$. Bu kapsamda borçlu tarafindan kendi iradesine bağlı olarak gösterilen borçlu veya üçüncü kişilere ait teminat olarak kabul edilebilecek ayni bir değer olan menkul ve gayrimenkuller, alacaklı tahsil dairesi tarafindan haczedilmektedir. Söz konusu mallar haciz altına aldığı anda teminat gösterilmiş olmaktadır. Gayrimenkuller haciz varakasına dayanılarak tapu sicil müdürlüklerine haciz tebliğ edilerek, menkuller ise mevcut haciz varakasına istinaden normal usulde haczedilmektedir $^{73}$.

70 Bayraklı, s. 37; Çelik, Kamu Alacakları, s. 49; Üstün, Teminat, s. 151; Gerçek, Kamu Alacakları, s. 167.

71 Gerçek, Teminat, s. 32.

72 Danıştay 7.D. T.30.11.1999, E.1997/3790, K.1999/3956: "Gayrimenkullerin teminat fonksiyonunu ifa edebilmeleri, haciz varakasına müsteniden haczedilmeleri ile mümkün olup gayrimenkulün teminat olarak kabulü istemini içeren dilekçe "teminat senedi" olarak kabul edilemez." (www.kazanci.com).

73

Koçak, s. 106. 
6183 sayılı Kanunda söz konusu eşyaların hangi değer üzerinden teminat altına alınacağına dair bir ifade yoktur. Ancak menkul ve gayrimenkullerin haczine yönelik genel değerleme hükümleri burada uygulanabilirdir ${ }^{74}$. Buna göre 6183 sayılı Kanun m.81 çerçevesinde menkul bir mal teminat olarak gösterildiğinde haciz yapan memurun takdir ettiği kıymet üzerinden teminat alınmış olmakta, borçlunun müracaatı veya tahsil dairesinin lüzum görmesi halinde bilirkişi marifetiyle değer biçilmektedir.

Gayrimenkul malın teminat gösterilmesi durumunda ise uygulamada emlak vergisi tarhına esas olan değer ile tapu değeri arasından düşük olanın teminat tutarı olarak tercih edildiği ifade edilmektedir ${ }^{75}$. Ancak 6183 sayılı Kanun m.91 doğrultusunda uyuşmazlık konusu edildiğinde, gayrimenkul malın satışı halinde geçerli olan bilirkişi takdiri üzerine satış komisyonu tarafından biçilen rayiç değerin esas alınması gerekecektir ${ }^{76}$.

Menkul veya gayrimenkul bir mal teminat olarak gösterildiğinde eşya üzerindeki tasarruf yetkisi kısıtlanmaktadır. Eşya üzerindeki mülkiyet hakkına yönelik sınırlandırmayı kabul ederek teminat gösterme tercihinde bulunmuş kişi için mümkün olan en süratli ve en az masraflı yolun kullanılarak teminat olarak gösterilen eşyanın gerçek değeri tespit edilmelidir. Bu noktada kamu alacaklısının, kamu borçlusunun menfaatini koruma yükümü altında olduğu hatırlanmalıdır.

6183 sayılı Kanunda teminat olarak gösterilen menkul veya gayrimenkul malın borçluya ait olması şartı koşulmamıştır. Kanunda ifade edildiği üzere üçüncü kişiler de borçlu lehine mallarını teminat olarak gösterebilmektedir. Ancak önceki düzenlemede üçüncü kişiler tarafından menkul ve gayrimenkul mallar teminat olarak gösterilememekteydi. Bu imkân 19.6.1963 tarih ve 251 sayılı Kanun ile yapılan değişiklik sonrası getirtilmiştir $^{77}$.

Diğer taraftan üçüncü kişilerin kendilerine ait malı borçlu lehine teminat göstermesi durumunda kamu alacaklısının bu iradeyi ortaya koyan özel belgeler istemesi olağan bir durumdur. Bu doğrultuda Tahsilat Genel Tebliğinde bu iradeyi açık bir şekilde gösteren imzalı muvafakat yazının bizzat tahsil dairesine getirtilmesi istenmektedir. Ancak üçüncü kişinin yazıyı bizzat getiremediği durumlarda, üçüncü kişi tarafından imzalanmış ve noter tarafından onaylanmış bir örneğin tahsil dairesine ulaştırılması da yeterli

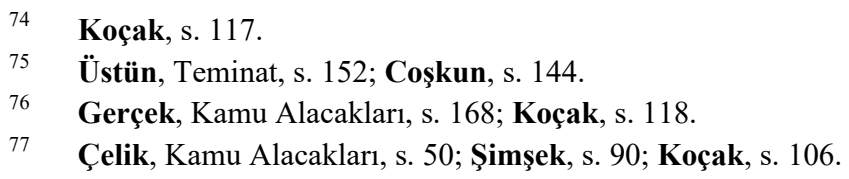


görülmüştür. Ayrıca Tebliğde bu muvafakat yazısının içeriğinde bulunması gerekli unsurlara da yer verilmiştir. Bu muvafakat yazısının alınması sonrasında kamu alacaklısı, haciz varakasına istinaden gayrimenkul mallar için tapu müdürlüğüne haciz tebliğ edecek, menkul mallar için ise haciz tutanağ1 ile haciz gerçekleştirecektir.

Borçluya veya üçüncü kişiye ait elbirliği mülkiyetindeki pay diğer ortakların tamamının muvafakatinin alındıktan sonra teminat olarak gösterilebilmektedir. Teminat olarak gösterilecek gayrimenkulün ipotekli olması durumunda, teminatı kabul edip etmemek alacağın tehlikeye düşme ihtimalini değerlendirecek olan kamu alacaklısına bağlıdır. Ayrıca teminat olarak gösterilen malların getirileri malın sahibi olan borçluya aittir ${ }^{78}$. Diğer taraftan şirket ortağ 1 tarafindan teminat gösterilen bir malın, ortağa isabet eden kısmı için değil borcun tamamı için teminat kabul edileceğini ifade etmek gerekir $^{79}$.

\section{C. Şahsi Teminat}

6183 sayılı Kanun m.10 hükmü maddi malvarlığı değerleri üzerine odaklanırken m.11'de şahsi teminat olan, şahsi kefalet konusu yer almaktadır. Bu düzenlemeye göre maddi bir varlık değil bir kişi kefil sıfatıyla teminat gösterilebilmektedir. Kanuna göre asıl olan kamu borçlusunun m.10'da yer alan değerleri teminat olarak sunmasıdır. Ancak gösterilmiş olan teminat unsurları ile kamu idaresinin isteğinin karşılanamadığı hallerde, bir kişinin şahsi kefalet hukuki biçimiyle teminat olarak kabul edilebileceği hüküm altına alınmıştır.

Kanunda açıkça bir öncelik sırası belirlendiğinden teminat istemine karşılık olarak borçlunun doğrudan şahsi kefalet sunabilmesi mümkün değildir. Örneğin kamu alacağını karşılamaya yetecek değerde taşınmazın bulunduğu sabitse bu taşınmazın teminat olarak gösterilmesi zorunlu olup, tahsil dairesi şahsi kefaleti kabul edemeyecektir ${ }^{80}$. Kanunda yer alan türde bir değerin bulunmadığı, miktar olarak yeterli olmadığ1 veya idarenin kabul etmediği hallerde şahsi kefalet gösterilebilmektedir.

Şahsi kefalet hem borçluya hem de kamu alacaklısına kolaylaştırıcı nitelikte bir imkân sunmaktadır ${ }^{81}$. Diğer taraftan 6183 sayılı Kanun m.11/3 
hükmüyle alacaklı tahsil dairesine şahsi kefaleti ve gösterilen kişiyi kabul edip etmeme konusunda takdir yetkisi verilmektedir ${ }^{82}$.

6183 sayılı Kanuna göre teminat olarak şahsi kefalet gösterebilmenin bazı koşulları vardır. Öncelikle Kanun şahsi kefalet sıfatı taşıyacak olan kişinin muteber olmasını istemektedir. Kanunda yer alan bu kavram şahsi kefaleti kabul edip etmeme konusunda idareye verilen geniş yetkinin tezahürüdür. Bu doğrultuda Tahsilat Genel Tebliğinde “... kabulü tahsil dairesinin ihtiyarına bırakılmak suretiyle..." ifadesine yer verilerek, muteber kişi konusunda tahsil dairesinin ikna beklentisine işaret edilmiştir.

Kamu alacaklısına şahsi kefalet ile güvence tesis edecek olan kişinin muteber kişi sıfatına sahip olması onun mali durumuna yönelik bir betimlemedir. Muteber kişi, güvenilir, taahhütlerine sadık kalan kişi anlamı taş1maktadır $^{83}$. Kamu alacaklısı için beklenilmesi gereken kamu alacağının tahsilinde güvenilir olunması ve borç ödeme kapasitesinin bulunmasıdır ${ }^{84}$. Diğer bir ifadeyle kefil olunacak gerçek veya tüzel kişinin ekonomik olarak yeterli olması onu muteber kılmaktadır. Bunun dışında kişiyi muteber kabul ettiren veya ettirmeyen diğer sebepler alacaklı tahsil dairesinin inceleme alanında değildir. Ayrıca şahsi kefalet olunacak kişi hukuken kefil olabilme ehliyetine sahip olmalıdır. Diğer taraftan alacaklı tahsil dairesi gösterilen tek kefille yetinmeyip, birden fazla kefilin gösterilmesini de isteyebilmektedir. $\mathrm{Bu}$ halde alacağın tamamı herhangi birisinden tahsil edebilecektir ${ }^{85}$.

Şahsi kefaletin teminat olabilmesinin diğer bir koşulu kefaletin türüne ilişkindir. 6183 sayllı Kanun m.11'e göre, sadece "müteselsil kefil ve müşterek müteselsil borçlu" şahsi kefalet olabilmektedir. Burada kefalet anlamında bir sorumluluk söz konusu olup, yükümlü düzeyinde bir borçluluğun bulunmadığının altını çizmek gerekir ${ }^{86}$. Kanunda yer alan bu kavram, 6193 sayılı Kanun m.11 düzenlemesinin yapıldığ 1 tarihte yürürlükte olan 818 sayılı Borçlar Kanunu m.487'de yer alan müteselsil kefaletin ${ }^{87}$ karşıllı̆̆ldır. Zira 818 say1lı Kanun, müteselsil kefil ve müşterek müteselsil borçlu sıfatıyla sorumlu olunması halini açıkça müteselsil kefalet başlığı altında

\footnotetext{
82 Karakoç, Genel Vergi, s. 513; Bayraklı, s. 43; Coşkun, s. 153; Ünsal, s. 21.

83 Bayraklı, s. 43.

84 Çelik, Teminat, s. 3.

85 Gerçek, Teminat, s. 38.

86 Şimşek, s. 91.

87818 sayılı Borçlar Kanunu m.487: "Kefil, borçlu ile beraber müteselsil kefil ve müşterek müteselsil borçlu sıfatı ile veya bu gibi diğer bir sıfatla borcun ifasını deruhde etmiş ise alacaklı asıl borçluya müracaat ve rehinleri nakde tahvil ettirmeden evvel kefil aleyhinde takibat icra edebilir. Bu babın hükümleri, bu nevi kefalete de tatbik olunur."
} 
düzenlemiştir. Şu an itibariyle yürürlükte olan 6098 sayılı Borçlar Kanun m.586'da yer alan müteselsil kefalet ${ }^{88}$ içerik olarak değişikliğe uğramıştır. Ancak şurası bir gerçek ki 6183 sayılı Kanun m.11'e göre teminat olarak şahsi kefaletin gösterilebilmesi için kefaletin, adi veya birlikte kefalet türünde değil müteselsil kefalet türünde olması gereklidir.

Adi kefalette kural olarak alacaklılar öncelikle borçluya başvurmalı, borçludan alacağın tahsil edilememesi durumunda kefile gidilmelidir. 6183 sayılı Kanun m.11 kapsamında şahsi kefalet gösterilmesi halinde ise asıl borçlu hakkındaki takibin sonuçsuz kalmasını beklemeye gerek duymadan kamu alacaklısı kefil aleyhine takip yapabilecektir ${ }^{89}$. Ayrıca şahsi kefaletin bu türde oluşu 6183 sayılı Kanun m.57 hükmünde yer alan; "kefiller bu kanun hükümlerine göre ve aynen asıl borçluların tabi oldukları usullerle takip olunur" ifadeleriyle uyum içindedir ${ }^{90}$. Bu uyum alacaklı tahsil dairesinin kefili doğrudan, asıl borçlu gibi takip etme hak ve yetkisini perçinlemektedir.

Şahsi kefaletin teminat olarak gösterilebilmesinin üçüncü koşulu şekil şartlarına uygun surette yapılmasıdır. Türk Borçlar Kanunu anlamında özel hukuk ilişkilerinde yapılan kefalet sözleşmelerinin geçerli olabilmesi için bazı şekil kurallarına uyulması gerekir. 6098 sayılı Borçlar Kanunu m.583'e göre: "Kefalet sözleşmesi, yazılı şekilde yapılmadıkça ve kefilin sorumlu olacağı azamî miktar ile kefalet tarihi belirtilmedikçe geçerli olmaz. Kefilin, sorumlu olduğu azamî miktarı, kefalet tarihini ve müteselsil kefil olması durumunda, bu sıfatla veya bu anlama gelen herhangi bir ifadeyle yükümlülük altına girdiğini kefalet sözleşmesinde kendi el yazısıyla belirtmesi şarttır. Kendi adına kefil olma konusunda özel yetki verilmesi ve diğer tarafa veya bir üçüncü kişiye kefil olma vaadinde bulunulması da aynı şekil koşullarına bağlıdır. Taraflar, yazılı şekle uyarak kefilin sorumluluğunu borcun belirli bir miktarıyla sınırlandırmayı kararlaştırabilirler. Kefalet sözleşmesinde sonradan yapılan ve kefilin sorumluluğunu artıran değişiklikler, kefalet için öngörülen şekle uyulmadıkça hüküm doğurmaz."

6098 sayılı Borçlar Kanunu m.586: "Kefil, müteselsil kefil sıfatıyla veya bu anlama gelen herhangi bir ifadeyle yükümlülük altına girmeyi kabul etmişse alacaklı, borçluyu takip etmeden veya taşınmaz rehnini paraya çevirmeden kefili takip edebilir. Ancak, bunun için borçlunun, ifada gecikmesi ve ihtarın sonuçsuz kalması veya açıç̧a ödeme güçsüzlüğ̈̈ içinde olması gerekir."

Karakoç, Kamu Alacakları, s. 174; Çelik, Kamu Alacakları, s. 55; Üstün, Teminat, s. 154; Barlass, s. 20; Gülseven, s. 91; Arslaner, s. 154; Koçak, s. 107. 
6183 sayılı Kanunun teminat olarak kabul ettiği şahsi kefaletin geçerliliği için ise Borçlar Kanunu m.583'de yer alanlardan ayrı, özel şekil kuralları bulunmaktadır. Buna göre şahsi kefaletin yazılı yapılması yeterli olmayıp, şahsi kefalet noterden onaylı bir sözleşmeyle tesis olunmalıdır.

Tahsilat Genel Tebliğinde şahsi kefaletin tespit edilecek şartlara uygun olarak noterden tasdikli sözleşmeyle tesis edileceği ve Tebliğ EK, 2'de yer alan şahsi kefalet senedi örneğinin kullanılacağı açıklanmıştır. Şahsi kefalet senedinde; kefil olanın kişisel bilgilerinin yanında kanuni dayanak, kefil olunan kişi, borç tutarı, alacaklı tahsil dairesi, tarih ve imza gibi bilgilere yer verilmektedir. Ayrıca, istenildiğinde tahsilat tarihine kadar hesaplanacak ferileri ile birlikte ödemeyi müteselsil kefil ve müşterek müteselsil borçlu sıfatıyla kabul ve taahhüt edildiği ifadeleri açıkça yer almaktadır. Böylece şahsi kefalet senedi içeriğinde kefilin takibi sürecinde karşılaşılabilecek olası hukuki uyuşmazlıklara önlem olacağı düşünülen içerik ve biçim oluşturulmuştur.

Teminat kurumunun niteliğine uygun olarak şahsi kefalet sözleşmesine dair Kanunun ve ayrıca idarenin özel şekil kuralları belirginleştirmesi kamu alacaklısının kendini güvenceye alma amacına yönelmektedir. Ancak diğer taraftan şahsi kefalet senedi içerik ve biçimi, kefilin kefalet senedinde ödemeyi taahhüt etiği borç miktarı ile sınırlı ve sadece kefil olunan bu borç için sorumlu olacağının da hukuki gerekçesidir.

6183 sayılı Kanun m.11/4'e göre kamu alacaklısına borç ödemesi yapılması durumunda ödeme yapıldığına dair kefile bir belge verilecektir. Şüphesiz bu belge asıl borçluya rücu için kullanılacak ispat aracıdır.

\section{Teminat Hükmünde Olan Eşya}

6183 sayılı Kanun m.12'de bazı eşyaların kanunen teminat hükmünde olduğu kabul edilmiştir. Buna göre Kanunda yazılı olan işletmelerin faaliyet alanından kaynaklanan kamu borçları için bu işyerlerindeki faaliyet kollarında kullanılan eşya ve malzeme, bunların kamu alacaklısı tarafından teminat istemine konu edilmesine veya borçlu tarafından teminat olarak gösterilmesine gerek duyulmadan doğrudan teminat hükmündedir. Ayrıca burada yer alan unsurların 6183 sayılı Kanun m.10 kapsamındaki bir değer olması da gerekli değildir. Ancak 1950'li yıllardaki ekonomik koşullar üzerine inşa edilmiş bu hükmün günümüzdeki kullanılma kabiliyeti ve işlevselliği tartışmalidir ${ }^{91}$. 
$\mathrm{Bu}$ maddeye göre sınırlı sayıda belirlenmiş olan; bar, otel, han, pansiyon, çalgılı yerler, sinemalar, oyun ve dans yerleri, birahane, meyhane, genelevler içerisinde bulunan eşya ve malzemeler kendiliğinden ve herhangi bir sözleşmeye dayanmadan Kanun gereği teminat hükmündedir. Ancak Kanunda bu eşya ve malzemelerin, sadece bu yerlerin işletilmesinden doğan kamu borçlarına karşılık teminat oldukları ifade edilmektedir.

$\mathrm{Bu}$ denli özel yetki içeren Kanun hükmündeki işyerleri ve bu işyerlerinin işletmesinden doğan kamu borçları kavramlarını genişletmeden, dar yorumlamak gerekir. Bu nedenle örneğin, Kanunda yer almayan lokanta veya spor salonunu bu yerlerden saymak mümkün değildir ${ }^{92}$. Ayrıca işletmenin faaliyetinden kaynaklanan gelir vergisi, kurumlar vergisi ve bunlara bağlı olarak kesilen vergi cezaları kapsama dahil olabiliyorken, işletmecinin bir başka gelir unsurundan doğan vergileri, ecrimisil alacağı, işletme sahibinin trafik para cezası veya emlak vergisi gibi borçları dahil edilemeyecektir $^{93}$.

6183 say1lı Kanun m.12'de sayılmış yerlerin işletilmesinden doğan kamu borçlarının tahsiline yönelik olarak kanunen teminat hükmünde kabul edilen unsurlara dair teminatın paraya çevrilmesi yoluyla takip ve tahsil sürecine girişilebilecektir. Diğer bir ifadeyle teminat haczi uygulanan bu eşya ve malzemenin kamu alacağının tahsilinde kullanılabilmesi için ayrıca haciz uygulanmasına gerek olmadan doğrudan paraya çevirme yapılabilmektedir. Ancak diğer taraftan Kanun koyucu bu düzenlemeyi söz konusu işletmelerin bu malları için teminatın lehe fonksiyonlarını kullandırmak değil aksine mükellefler için bir tercih olan teminat göstermeyi tercih olmaktan çıkartarak bir tür engel oluşturmak için ihdas etmiş olduğundan, bu durum kamu alacaklısının diğer cebri takip ve tahsil yöntemlerini uygulama hak ve yetkisini ortadan kaldırmamaktadır ${ }^{94}$.

6183 sayılı Kanun m.12'de teminat hükmünde olan eşyalar belirlenmiş olmakla birlikte bazı haller istisna olarak sayılmıştır. İstisna olarak düzenlenmiş olan eşya ve malzemeler kanunen teminat hükmünde kabul edilen eşyaların dişında kabul edilecektir.

6183 sayılı Kanun m.12/1 hükmü 2004 sayılı İcra ve İflas Kanunu m.270 ve m.271 hükümlerini bu kapsamdaki kanuni teminattan istisna

\footnotetext{
92 Gerçek, Teminat, s. 36; Coşkun, s. 160.

93 Çelik, Kamu Alacakları, s. 51; Gerçek, Kamu Alacakları, s. 169; Gülseven, s. 93; Arslaner, s. 152.

94 Barlass, s. 23. Ayrıca bu yönde bknz. Bahçeci, s. 283.
} 
tuttuğu için buradan doğan alacak karşısında söz konusu eşya ve malzeme teminat dış1 olacaktır. İIK, m.270 ve m.271 hükümlerinde kiralayanın, kira hakk1 nedeniyle kiralanan yerdeki eşya ve malzeme üzerindeki hapis hakkının haczi hususu yer almaktadır. Dolayısıyla bu yerlerdeki eşya ve malzeme üzerindeki hapis hakkına dayanılarak hacizli malın satışı gerçekleştirildiğinde kira alacağı kamu alacağına karşı öncelikli olacak, diğer bir ifadeyle satıştan elde edilen bedelle öncelikle kira alacağı ödenecektir ${ }^{95}$.

6183 sayılı Kanun m.12/2 hükmünde ise noterden onaylı kira sözleşmesinde gayrimenkul sahibinin demirbaşı olarak kaydedilen eşya ve malzemelerin teminat hükmünde sayılmayacağı ifade edilmektedir. Ayrıca otel, han ve pansiyonlardaki misafir ve kiracıların kendilerine ait eşyalar da istisna kapsamındadır.

6183 sayılı Kanun m.12/3'de teminat hükmünde olan eşya üzerinde üçüncü kişilerin istihkak iddialarının kamu alacaklısının teminat hakkını ihlal etmeyeceğine hükmedilmektedir. Böylece kamu alacaklısı, istihkak iddialarının sebebiyet verebileceği olası olumsuz sonuçlara karşı korunmuştur. Ancak 6183 sayılı Kanun burada Medeni Kanun m.688 ile Borçlar Kanunu m.222 hallerini ayrıca istisna olarak belirlemiştir. Kanun metninde yer alan 743 sayılı Medeni Kanun m.688 mülkiyeti muhafaza kaydıyla yap1lan satış sözleşmesi, 818 sayılı Borçlar Kanunu ise taksitle yapılan satışlarla ilgilidir. Ancak her iki kanun yürürlükten kaldırılmış olduğundan içerdiği hükümlerden yola çıkılarak yapılacak değerlendirme sonucu 743 sayılı Medeni Kanun m.688 olarak 4721 sayılı Medeni Kanun m.764, 818 sayıl1 Borçlar Kanunu m.222 olarak 6098 sayılı Borçlar Kanunu m.271 ele alınmalıdır. Diğer taraftan istisnaların sıralı bir şekilde yer almasının ve Kanunun bu hükmünün yeni kanunlara uygun surette düzeltilmesinin gerekli olduğunun altı çizilmelidir ${ }^{96}$.

$\mathrm{Bu}$ düzenlemeler çerçevesindeki istihkak iddiaları kamu alacaklısına karşı ileri sürülebilecektir ${ }^{97}$. Bu halde tahsil dairesinin bulunduğu yerdeki adli yarg1 organlarının yetkili ve görevli olduğu istihkak iddiasına yönelik davada, davasını kazanan üçüncü kişi malın aynını veya değerini borçludan talep edebilecektir ${ }^{98}$.

\footnotetext{
95 Bknz. Çelik, Kamu Alacakları, s. 51; Bayraklı, s. 39; Üstün, Teminat, s. 152; Koçak, s. 112; Gülseven, s. 94.

96 Çelik, Teminat, s. 3.

97 Bknz. Candan, s. 94; Bayraklı, s. 40-41; Arslaner, s. 153.

98

Çelik, Kamu Alacakları, s. 53; Coşkun, s. 160.
} 


\section{TEMINATA DAİR ÖZELLİKLİ HALLER}

\section{A. Genel Olarak}

Teminat isteme koşulları oluştuğunda teminat isteme yetkisine sahip alacaklı tahsil dairesi kamu borçlusuna teminat gösterilmesini isteyen bir yazı tebliğ etmekte sonrasında kişinin tutumuna göre farklı hukuki sonuçlar doğmaktadır. Kamu alacaklısının teminat istemi tek başına doğrudan doğruya borçlunun malvarlığı değerleri üzerindeki mülkiyet hakkından kaynaklanan yetkileri sınırlandırmamaktadır. Bu yazı üzerine kamu borçlusu teminat gösterdiğinde kamu alacağı güvence altına alınmış olmakta diğer koruma önlemlerine başvuru ihtiyacı olmadan borcun ödenmemesi ihtimalinde kamu alacaklısı, teminatın paraya çevrilmesi yoluyla takip ve tahsil gerçekleştirebilmektedir. 6183 sayılı Kanun m.54'e göre bu halde cebri takip ve tahsil teminatın paraya çevrilmesi veya kefilin takibi (6183 sayılı Kanun, m.56-57) yoluyla olabilmektedir ${ }^{99}$. Bu yol haciz ve iflas yolundan daha kolay ve az masraflıdır ${ }^{100}$.

Ayrıca borçlunun teminat göstermiş olması kamu alacaklısına alacağı tahsil edebilmesi için zaman kazandırmaktadır. Zira 6183 sayılı Kanun m.103'e göre kamu alacağının teminata bağlanmış olması tahsil zamanaş1minı kesecektir ${ }^{101}$.

Borçlu teminat gösterdiği malvarlığı üzerindeki mutlak tasarruf yetkisini kaybetmektedir. Teminat, kamu alacaklarını güvence altına almaya yönelik zincirin ilk halkası ve tetikleyicisidir ${ }^{102}$. Teminat isteme yazısı sonrasında kamu borçlusu teminat göstermediğinde ihtiyati haciz veya ihtiyati tahakkuk uygulanacaktır ${ }^{103}$. Tahsil dairesinin teminat isteme yazısı her iki tarafı ilgilendiren bireysel bir idari işlem niteliğinde olduğundan dava konusu edilebilir.

99

100
Barlass, s. 18.
Bayraklı, s. 41.

Danıştay 7.D. T.14.10.1997, E.1996/766, K.1997/3438: “... 6183 sayılı Kanunun 102. maddesinde tahsil zamanaşımına ilişkin düzenlemeye yer verildikten sonra, 103. maddesinde de, zamanaşımını kesen haller 10 bent olarak sayılmıştır. Anılan maddenin 8 . bendinde, amme alacağının teminata bağlanmasının, zamanaşımını keseceği belirtilmiş, maddenin son paragrafinda ise, amme alacağının teminata bağlanması halinde, zamanaşımının, teminatın kalktığı tarihin rastladığı takvim yılının ilk gününden itibaren başlayacağı hükme bağlanmıştır." (www.kazancı.com).

Çelik, Teminat, s. 1.

Çelik, Kamu Alacakları, s. 58; Üstün, Teminat, s. 155; Gerçek, Kamu Alacakları, s. 171. 
Teminata yönelik özellikli hallerin ele alınacağ bu bölümde teminatın değiştirilmesi, tamamlattırılması, korunması, iadesi ve teminat istemine karşı dava yolu irdelenmektedir.

\section{B. Teminatın Tamamlattırılması veya Başka Teminat Gösterilmesi ve Teminatın Değiştirilmesi}

6183 sayılı Kanun m.10 hükmünün son iki fikrası teminat gösterilen unsurların değişimi konusunda kamu alacaklısı ile kamu borçlusu arasında denge kurmaktadır. Bu düzenlemeler her iki tarafa teminat gösterildikten sonra teminat unsurlarını değiştirebilme imkânı tanıyan kolaylaştırıcı niteliktedir. Diğer taraftan Kanunun bu hükümleri kamu alacaklısına teminat gösterilen değerin maddi karşllığının sürekli izlenilmesi yükümlülüğü vermektedir.

6183 sayılı Kanun m.10'da öncelikle kamu alacaklısına teminatı tamamlattırma veya başka teminat gösterilmesini isteme hak ve yetkisi ele alınmıştır. Buna göre teminat olarak gösterilen değer sonradan tamamen veya kısmen değerini kaybeder veya borç miktarı artarsa, kamu alacaklısı teminatın tamamlattırılmasını veya başka teminat gösterilmesini isteyecektir. Örneğin, bir aracın, makinanın veya eşyanın modelinin eskimesi, hisse senedinin değer değişimi, dövizdeki ani hareketlikler gibi malın özelliğinden kaynaklanan değer kayıplarında teminatın tamamlanması veya yerine başka teminat gösterilmesi gerekecektir ${ }^{104}$. Yine bu doğrultuda gecikme faizi veya gecikme zammı gibi borç miktarını artıran hallerde bu yol işletilebilmektedir $^{105}$. Burada dikkat çekici olan bu hak ve yetki, yeni bir teminat isteme talebi olmadığından daha önceki teminat istemiyle bağlantı kurulmasının zorunlu olmasıdır. Diğer bir ifadeyle borç miktarındaki artışın değerlendirilmesinde sadece teminat istemine konu olan borç esas alınacaktır. Süreç içinde farklı sebeplere dayalı olarak ortaya çıkmış olan yeni bir kamu borcu için tamamlattırma yapılmamalı, koşullarının varlı̆̆ yeni teminat isteme süreci işletilmelidir.

Teminatın değerini kaybettiği veya borç miktarının arttığı doğrultusunda tahsil dairesince karar alınacak, asıl teminat istemindeki usul ve sürelere uygun olarak kamu borçlusuna istek iletilecektir ${ }^{106}$. Kanunda yer alan ifadelerden değer kaybı veya borç miktarı artışı yaşanması halinde kamu alacaklısının ihtiyarı değil, zorunlu olarak bu süreci işletmesi gerektiği anla-

\footnotetext{
104 Çelik, Kamu Alacakları, s. 57; Candan, s. 91; Üstün, Teminat, s. 154; Coşkun, s. 146.

105 Coşkun, s. 146; Yapar, s. 117.

106 Çelik, Kamu Alacakları, s. 57; Gerçek, Kamu Alacakları, s. 170; Şimşek, s. 92.
} 
şılmaktadır. Bu zaruret kamu alacaklısına, teminat gösterilen değerin güncel bedel karşıllı̆ını sürekli takip etme mükellefiyeti yüklemektedir.

Teminatın tamamlatılması veya başka teminat gösterilmesi isteğinin kamu borçlusu tarafından yerine getirilmemiş olması durumunda teminatsız kalan kısım için ihtiyati haciz uygulanacaktır ${ }^{107}$. Burada Kanunda açık bir hüküm bulunmamakla beraber ihtiyati haciz tutarının, teminatın son değeri ile kamu borcu arasındaki tutar kadar olmasını beklemek gerekir ${ }^{108}$.

Diğer taraftan 6183 sayılı Kanun m.10 kamu borçlusuna teminatı kısmen veya tamamen, aynı değere sahip, Kanunda kabul edilen başka değerlerle değiştirebilme hak ve yetkisi vermektedir. Kamu alacaklısı herhangi bir seçim yaparak borçluya kendi istediği değeri gösterme dayatması yapamaz. Kanunda yer alan dilediği türden teminatı daha önceden göstermiş olan kamu borçlusu aynı zamanda herhangi bir gerekçe ileri sürmeden bu teminatı kısmen veya tamamen değiştirebilmektedir. Teminatın Kanunda yer alan türden ve önden gösterilen teminatla aynı değerde olması halinde bu değiştirme isteği kabul edilmek zorundadır ${ }^{109}$. Teminatın aynı değerde olması daha önceden gösterildiği gibi kamu alacağını karşılamaya yetecek düzeyde olunmasıdır. Borç tutarının gecikme faizi vb. sebeplerle artması halinde değiştirilecek teminat için değiştirilme anındaki yeni tutar esas alınmalıdır ${ }^{110}$. Teminat değiştirildiğinde önceki teminat serbest bırakılmalı, örneğin şahsi kefalet değiştirilerek yerine makine veya gayrimenkul gösterildiyse kefil olan kişinin sorumluluğuna artık gidilmemelidir ${ }^{111}$.

Burada kamu alacağının güvenceye alınması konusunda zafiyet endişelerine neden olabilecek hallerde değişiklik isteğinin kabul edilmemesi gündeme gelebilmektedir ${ }^{12}$. Bu noktada bir taraftan teminatın tamamlatt1rılması veya yerine başka teminat gösterilmesi diğer taraftan teminatın değiştirilmesi hak ve yetkilerinin iyi niyetli olarak kullanılması halinde hukuk düzeninin koruması altında olduğunun altını çizmek gerekir.

\footnotetext{
107 Üstün, Teminat, s. 155; Koçak, s. 120; Yapar, s. 117.

108 Çelik, Teminat, s. 4.

109 Candan, s. 92; Gerçek, Kamu Alacakları, s. 170.

110 Coşkun, s. 146; Yapar, s. 118.

111 Gerçek, Teminat, s. 258-259.

112 Bknz. Çelik, Kamu Alacakları, s. 58. Danıştay 4.D. E.1973/6300, K.1974/3759: “... "Teminatın değiştirilmesi” yolundaki borçlu isteminin, yeni gösterilen teminatın amme alacağının garantiye alınmasında mahzurları bulunması nedeniyle reddedilmesinde kanuna aykırılık yoktur ...” Bknz. Yerlikaya, Gökhan Kürşat: Açıklamalı ve İçtihatlı 6183 Sayılı Amme Alacaklarının Tahsil Usulü Hakkında Kanun Şerhi, (XII Levha), İstanbul 2012, s. 72.
} 


\section{Teminatın Korunması ve İadesi}

6183 sayılı Kanunda haczedilen menkul malların korunmasına ilişkin hükümleri ihtiva eden m.82 ile koruyacak olanların sorumluluklarını düzenleyen m. 83 ve gayrimenkul mallar ile gemilerin haczini düzenleyen m. 88 hükümleri doğrultusunda, teminat gösterilen mallar korunmaktadır ${ }^{113}$. Haczedilen menkul ve gayrimenkul malların korunmasına yönelik tedbirler tahsil dairesi tarafından kendiliğinden alınmalıdır. 6183 sayılı Kanun m.82 çerçevesinde niteliğine bağl1 olarak menkul mallar tahsil dairesi bünyesinde korunabileceği gibi, uygun yerde muhafazaya alınması, güvenilir bir kişiye veya güvenilir kişinin kefaleti altında borçluya veya zilyedinin kendisine de bırakılabilmektedir. $\mathrm{Bu}$ noktada alacaklı tahsil dairesinin takdir yetkisi bulunmaktadır. Tahsil dairesinin malları teslim ettiği kişiler, alacaklı kamu idareleri tarafından yapılacak ilk talep üzerine malları derhal teslim edilen zamandaki durumuna uygun şekilde geri vermelidir. Aksi halde geri verilmeyen malların değeri tutarında borçlu sayılarak, sorumluluklarına gidilebilecektir ${ }^{114}$.

Teminat olarak gösterilen mallar konusunda gerekli tedbirleri almak tahsil dairesinin yükümlülüğü olduğundan bunların çalınması, kaybolması veya zarar görmesi durumunda hizmet kusuru çerçevesinde sorumluluk doğabilecektir ${ }^{15}$. Ayrıca 6183 sayılı Kanun m.88'e göre haczedilen gayrimenkul ve gemilerin idaresi ve işletilmesi ile menfaat ve hasılatın toplanması için gereken tedbirler tahsil dairesince alınmalıdır. Teminat olarak kabul edilen malların getirileri mal sahibine aittir $^{116}$.

6183 sayılı Kanunda teminatın iadesine yönelik bir hüküm bulunmamaktadır. Teminat isteme koşullarının sonradan ortadan kalktığ 1 halde teminat gösterilen değerlerin akıbetinin ne olacağ 1 yasal bir çerçeveye kavuşturulmalıdır. Diğer taraftan teminatın alınış nedeni ortadan kalktığında teminatın iade edileceğini ifade etmek gerekir ${ }^{117}$. Bu halde teminat istemine gerek olmadığının süreç sonunda idarece anlaşılması, teminat isteme işlemin yargı kararıyla iptal edilmesi, kamu alacağının ödenmesi veya kamu alacağına yönelik mahkemenin terkin kararı vermesi gibi hallerde gösterilmiş bulunan teminat iade edilmelidir. Kamu alacağının kısmen ortadan kalktığı

\footnotetext{
113 Gerçek, Kamu Alacakları, s. 170; Yapar, s. 119.

114 Gerçek, Teminat, s. 256; Coşkun, s. 145.

115 Gerçek, Kamu Alacakları, s. 170; Yapar, s. 119.

116 Koçak, s. 119.

117 Çelik, Kamu Alacakları, s. 58; Candan, s. 92; Gerçek, Kamu Alacakları, s. 170; Arslaner, s. 151; Yapar, s. 121.
} 
hallerde iade mükellefiyeti olmamakla beraber kamu alacağı son bulduğu ölçüde, elverişliyse teminatta iade yapılması daha adildir ${ }^{118}$.

Ayrıca AYM'ye göre, kamu alacağının tahakkukunun makul sayılmayacak derecede uzun bir zaman alması durumunda teminatın idarece kald1rılması, kaldırılmadığı takdirde meydana gelecek zararın dava yoluyla tazmin edilmesi mümkündür ${ }^{119}$.

Diğer taraftan alacaklı tahsil dairesi teminatı hangi alacak için istemişse sadece onun tahsili amaciyla elinde tutabilecek, öncesinde var olan veya sonradan ortaya çıkmış başka borçlar için koşulları varsa ve idarenin böyle bir iradesinin bulunması durumunda ayrıca teminat isteme süreci işletilecektir $^{120}$. Alacaklı kamu idaresi halihazırda almış olduğu teminatı başka bir alacak için kullanamayacaktır. Bu noktada gösterilen teminat ile kamu borcu arasında özgüleme ilişkisi bulunduğuna dikkat etmek gerekir.

\section{Teminat İstemine Karşı Dava Yolu}

6183 sayılı Kanuna göre teminat isteminin karşılanmaması kamu borçlusu aleyhine bazı hukuki sonuçların doğmasına neden olmaktadır. Kamu alacağını güvenceye bağlayan teminat diğer koruma önlemleriyle kıyaslandığında kamu alacaklısı için kolay tahsili ifade ederken, borçlunun da katlanacağ ${ }_{1}$ daha hafif nitelikteki bir önlemdir. Kamu alacaklısı, teminat istemine karşı kayıtsız kalınması halinde diğer koruma önlemlerine başvurabilmektedir. Bu haliyle kamu borçlusu ihtiyati haciz veya ihtiyati tahakkukun uygulanması durumuyla karşı karşıya kalacaktır.

Kişinin menfaatini etkileyen ve ona belli hukuki sonuçlara katlanma yükümü yükleyen teminat isteme işlemine karşı idari yargıda dava açılabilmektedir. Teminat isteme yazısı, kamu borçlusunun menfaatini etkileyen, hukukunda değişiklikler oluşturan, icrai, yükümlendirici ve kimi sonuçlarla karşılaşacağ1 bireysel bir idari işlemdir ${ }^{121}$. Buna göre kesin ve yürütülmesi

\footnotetext{
118 Gerçek, Teminat, s. 260; Yapar, s. 121.

119 Anayasa Mahkemesi T.15.5.2019, E.2018/142, K. 2019/38.

120 Candan, s. 92; Arslaner, s. 154; Yapar, s. 122.

121 Candan, s. 89; Gerçek, Teminat, s. 50; Taylar, s. 77-78; Şentürk, s. 18; Üstün, Gül: İdare Hukuku Boyutuyla 6183 Sayılı Amme Alacaklarının Tahsil Usulü Hakkında Kanun Uygulamalarında Görev Sorunu, (XII Levha), İstanbul 2013, s. 143-144. Danıştay 4.D. T.15.10.2008, E.2008/5821, K.2008/3601: "Vergi idarelerinin vergi hukuku alanında tesis ettikleri ve verginin tahsilinin güvence altına alınmasına ilişkin işlemlerden olan teminat istenmesini gerektiren haller aynı zamanda ihtiyati haczin nedenini oluşturmakta olup teminat gösterilmemesi halinde hedef aldığı kişi ya da kişilerin varlıklarının ihtiyaten haczi yoluna gidilebileceğinden, bu kişilerin menfaatini etkileyen
} 
zorunlu idari işlem sıfatını haiz teminat isteme işlemine karşı Anayasa m.125 uyarınca dava açılabilmektedir ${ }^{122}$. İdari yargıda açılacak olan dava, iptal davası niteliğindedir. Burada teminat isteme yazısının yetki, şekil, sebep, konu ve maksat unsurları yönlerinden hukuku uygunluğu denetlenecek, işlemin hukuka aykırılığına karar verildiği halde işlem, yapıldığı andan itibaren geçersiz olacaktır.

$\mathrm{Bu}$ davanın konusu teminat isteme işleminin iptali olduğundan teminat isteminin Kanuna uygun surette icra edilip edilmediği incelenmelidir. Diğer bir ifadeyle 6183 sayll Kanun m.9/1 ve m.9/2'de yer alan teminat isteme koşulları, teminat isteme yetkisi ve usulü, idari işlemin unsurları boyutuyla ele alınarak işlemin hukuka aykırı olup olmadığına karar verilmelidir. Örneğin 6183 sayılı Kanun m.9/2 kapsamındaki bir teminat isteminde Türkiye'de ikametgâhın bulunduğu veya kamu alacağının tahsil tehlikesi içinde bulunmadığı iddia edildiğinde, yargı organı bu hususu inceleyecektir. Bu doğrultuda, teminat istenmesini gerektiren koşulların mevcut olmaması halinde sebep, alacaklı tahsil dairesinin yetkili olmayan idari organı tarafindan imza edilmesinde yetki gibi idari işlem unsurlarındaki hukuka aykırılıklar denetlenecektir ${ }^{123}$. Ayrıca vergi incelemeye yetkili kişilerce tahmini bir büyüklük kıstas alınarak teminat tutarı hesaplandığı için istenilen teminat tutarının haksız ve hukuka aykırı olduğu da dava edilebilecektir ${ }^{124}$.

İşlemin hukuka uygunluğunun denetimi işlemin tesis edildiği tarihteki duruma bakılarak yapılmalıdır. Teminat istenmesini gerektiren durum nedeniyle yapılan tarhiyatın, açılan dava sonucunda iptal edilerek ortadan kaldırılmış olması, teminat isteme işlemini doğrudan hukuka aykırı kılmayacak$\operatorname{tur}^{125}$. Tarhiyat işlemine karşı açılan davan sonucunun beklenilmesine gerek olmadığ gibi bu dava sonucuna göre doğrudan teminat istemi işleminin hukuka aykırı olup, olmadığ kararı verilmemelidir. Teminat isteme işleminin Kanuna uygun halde olup olmaması, yapılacak tarhiyat işlemlerinden

hukuki sonuçlar meydana getiren dava konusu teminat istenilmesine ilişkin işlem kesin ve yürütülmesi zorunlu bir idari işlem niteliği taşımaktadır.” (www.kazancı.com).

Teminat isteminin kesin nitelik taşımakla beraber yürütülebilir bir sonuç doğurmadığı, teminat istemine değil ihtiyati haciz işlemine karşı dava açılabileceği yönündeki görüşleri için bknz. Bahçeci, s. 169.

Üstün, s. 145.

Bknz. Taylar, s. 77-78.

Candan, s. 89. Danıştay VDDGK T.18.11.2005, E.2005/148, K.2005/255: "Teminat istemine ilişkin işlemin iptali istemiyle açılan davada, tarhiyata karşı açılan davanın sonucuna göre karar verilmesinde yasaya uygunluk bulunmamaktadır." (www.kazanc1.com). 
ayrı ve bağımsız bir dava konusudur ${ }^{126}$. Her iki işleme karşı dava açılması hallerine yönelik olarak işlemler arasında Kanun tarafindan kurulmuş bir bağ yoktur.

Kanun koyucu teminat istemi ile bu istemin nedenine bağlı oluşabilecek tarhiyat işlemini birbirinden ayrı ele almıştır. Zira teminat isteyebilmek için tarh işlemine veya kesinlik kazanmış bir kamu alacağı varlığına ihtiyaç yoktur. Kanunda sayılmış olan nedene “... temas eden ...” bir kamu alacağ1 için gerekli işlemlere başlanılmış olması teminat istemi için yeterli görülmüştür. Bu halde kamu alacağı tahsilinin tehlikeye girme ihtimaline karşı önlem mahiyetini haiz teminat kurumu vergilendirme işlemleri üzerine kurulu değildir. Teminat istemi kendi bütünü içinde ayrı unsurlara sahip idari bir işlemdir.

Diğer taraftan kamu alacağının yarg1 kararıyla ortadan kalktığı veya olmadığının tespit edildiği hallerde, idarenin teminatın kaldırılması ve iadesi işlemi tesis etmesi gerekeceği bir hakikattir. Kesinleşmiş bir yargı kararıyla kamu alacağ1 varlığ1 ihtimali ortadan kalktığında, gösterilmiş olan teminat artık iade edilmelidir. Teminatın iade edilmemesi halinde meydana gelmiş olan zararin dava yoluyla tazminine gidilebilecektir.

Teminat istemine karşı dava açılabilmesinin yanında 6183 sayılı Kanun m.9-12 arasında dava konusu edilebilecek farklı idari işlemler de bulunmaktadır. Örneğin 6183 sayılı Kanun kapsamında olduğu iddia edilerek gösterilmiş bir değerin alacaklı tahsil dairesi tarafından kabul edilmemesi işlemi, teminatın değiştirilme talebinin reddi işlemi, tahsil dairesinin teminatın tamamlattırılması veya yerine başka teminat gösterilmesini isteme işlemi,

126 Bu konuda Danıştay’ın farklı sonuçlara ulaştığı kararları bulunmaktadır. Danıştay VDGGK, T.29.11.2002, E.2002/360, K.2002/418: "Kaçakçılık eyleminin varlı̆̆ını gösteren ve bu cezanın uygulanmasını gerektiren bir işleme başlanması, ilgiliden teminat istenmesi ve hakkında ihtiyati haciz uygulanmasına yeterli ise de bu işlemlerin dayanağ olan tarhiyatın yargı kararıyla kaldırılması karşısında işlemlerin de iptali gerekmektedir." (www.kazanc1.com). Danıştay VDDGK T.9.10.1998, E.1997/11, K.1998/260: "İhtiyati haciz ve teminat istem yazısına karşı açılan davada işlemin dayanağını oluşturan vergi ve cezaların yargı kararıyla kaldırıldığı göz önüne alınmadan verilen karar hukuka uygun değildir." (www.kazancı.com). Danıştay 3.D. T.9.5.2013, E.2013/581, K.2013/1700: "Dava, re'sen salınan katma değer vergisi ve özel tüketim vergisi alacağının güvence altına alınması amacıyla tesis edilen teminat isteme işleminin iptali istemine ilişkindir. Mahkemece özel tüketim vergisi, katma değer vergisi tarhiyatının kaldırıldığı anlaşıldığından, söz konusu vergi borçlan sebebiyle teminat istenmesi yönünde tesis edilen davaya konu işlemde yasal isabet bulunmadığı gerekçesiyle işlemin iptal edilmesinde isabetsizlik görülmemiştir." (www.kazanc1.com). 
şahsi kefaletin kabul edilmemesi işlemi, teminatın iade edilmesine ilişkin yapılan talebin reddi işlemleri için iptal davası açılabilecektir.

Diğer taraftan alacaklı tahsil dairesinin sorumlu tutulduğu hallerde, sebebiyet verdiği zararın tazminine yönelik olarak tam yargı davası açabilmek mümkündür. Bu çerçevede teminat isteme işleminin iptali ve hukuka aykırı şekilde tesis edilen teminat isteme işlemi nedeniyle uğranıldığı iddia olunan zararın tazmini talebiyle dava yoluna başvurulabilecektir.

\section{6183 SAYILI KANUNDAKI TEMINAT KURUMUNUN ANAYASAYA UYGUNLUK SORUNU}

6183 sayılı Kanun m.9'da yer alan teminat kurumunun ihtiva ettiği anlamın kamu otoritesini baskın tutan eğilimi Kanun hükmünün Anayasaya uygunluk sorununu tartışmayı gerektirmektedir. 6183 sayılı Kanun m.9/1-2 fikraları Anayasaya aykırı olduğu ileri sürülerek, İstanbul 6. Vergi Mahkemesi tarafindan somut norm denetimi yoluyla Anayasa Mahkemesinin önüne getirtilmiştir. 6183 sayılı Kanun m.13/1 (ihtiyati haciz) hükmünün de ele alındığı itirazda; 6183 sayılı Kanun çerçevesinde mükellefler hakkında haciz işlemi tesis edilebilmesi için tahakkuk, ödeme emri gibi süreçlerin tamamlanmasının gerektiği, teminat isteme ve ihtiyati haciz işlemlerinin uygulanabilmesinde vergi incelemesine başlanılmış olmasının yeterli görüldüğg̈, henüz ortada bir tarh işlemi olmadan ileride doğması muhtemel bir kamu alacağının tümünün teminat ve ihtiyati hacze konu edilebilmesinin hukuk devleti ilkeleriyle ve mülkiyet hakkıyla bağdaşmadığı iddia edilerek Kanun hükümlerinin Anayasa m.2 ve m.35'e aykırı olduğu iddia edilmiştir.

Anayasa m.2, m.13 ve m.35 hükümleri çerçevesinde itirazı ele alan Anayasa Mahkemesi Kanun hükümlerinin Anayasaya aykırı olmadığına oybirliği ile karar vermiştir ${ }^{127}$. Anayasa Mahkemesinin gerekçeli kararı bir taraftan teminat kurumunun anayasaya uygun olduğuna dair hukuki gerekçeleri ihtiva ederken diğer taraftan kurumun hukuki çerçevesine yönelik somut belirlemeler içermektedir. 6183 sayılı Kanun m.9/1 fikrası üzerine yoğunlaşan gerekçeli karardaki bazı hususları çalışmamız kapsamında ele almak gerekir.

Mahkemenin gerekçeli kararında öncelikle teminat kurumunun hukuki niteliği belirlenmiştir. Buna göre teminat cebri takip ve tahsile yönelik bir işlem olmayıp, kamu alacağının tahsilinin tehlikeye girmesini önlemek amacıyla, alacak henüz tahsil aşamasına gelmeden önce uygulanabilen geçici 
nitelikte bir tedbirdir. Kararda, teminat istemenin konusunun henüz tarh ve tebliğ edilmemiş, dolayısıyla tahakkuk etmemiş alacaklar oluşturabileceği, bu tür alacaklar yönünden kesinleşmiş bir kamu borcundan söz edilemeyeceği için anılan güvencelerin muhatabı olan mükellef ya da sorumluların henüz kamu borçlusu olamayabileceği tespiti yapılmıştır. Teminat kurumunun Kanundaki düzenlemelerine de yer verilen kararda, teminat gösterilen mal varlığı üzerinde idarenin icrai bir eyleminin olmadığına bu yönüyle teminatın, muhtemel kamu borcu karşısında kamu alacaklısını rahatlatan ve devlete, alacağın tahsili hususunda güvence veren bir önlem olduğuna işaret edilmiştir. Teminat istemenin mülkiyet hakkını hukuken ortadan kaldırmadığ 1 ancak mülkiyet hakkından kaynaklanan yetkileri kısıtladığ 1 , bunun bir hak kısıtlaması teşkil ettiğinden ölçülü olup olmadığının araştırılması gereğine değinilmiştir.

6183 sayılı Kanunun genel gerekçesinde yer alan, kamu alacaklarının takip ve tahsilinde genel takip sisteminden ayrı ve daha kolay, seri ve etkili usuller içeren özel bir takip sisteminin gerektiğine dair ifadelere değinilen gerekçeli kararda, mükelleflerin vergilendirmeye ilişkin anayasal yükümlülüklerini zamanında ve eksiksiz olarak yerine getirmemelerinin devletin vergi kaybına uğramasına yol açabileceği, vergi alacağının tehlikeye girmesine neden olabilecek bu halde teminat kurumunun, henüz tahakkuk etmemekle birlikte tahsil edilebilirliği tehlikeye giren kamu alacağının güvence altına alınması amacıyla düzenlendiği ve dolayısıyla meşru bir amaca dayandığı görüşüne ulaşılmıştır. Ayrıca söz konusu amaca ulaşmada elverişli bir araç olduğu da ifade edilmiştir.

Anayasa Mahkemesinin gerekçeli kararında ayrıca, toplumun kolektif ihtiyaçlarını gidermeyi esas alan kamu hizmetlerinin aksatılmadan yürütülebilmesi için kamu alacaklarının süresinde tahsilinin büyük önem taşıdığ1, kamu alacağının tahsilini tehlikeye düşürebilecek bazı durumlar için bu alacağın güvence altına alınmasına yönelik birtakım koruyucu tedbirlerin öngörülmesinin doğal ve Anayasa'ya aykırı olmamak koşuluyla Kanun koyucunun takdir yetkisi kapsamında olduğu ifadelerine yer verilmiştir. $\mathrm{Bu}$ konuda mülk sahibine kaçınılmaz olandan aşırı bir külfet yüklenmemesi koşuluyla, muhtemel bir alacağın güvence altına alınarak etkisizleşmenin önüne geçilmesi için ihtiyaç duyulan tedbirlerin alınması ve bu tedbirler kapsamında kamu makamlarının mülk üzerinde belli bir süreyle hukuki tasarruflarda bulunulması, devletlerin geniş takdir yetkisi içinde değerlendirilmiştir.

Bu bakımdan güvence olarak gösterilen mal varlığı üzerinde idarenin doğrudan doğruya uyguladığ 1 icrai bir fiile neden olmayan teminat isteme 
tedbirinin, tahsili riskli olarak değerlendirilen kamu alacakları bakımından gerekli olmadığının söylenemeyeceği, teminat isteme yolunun borçluya belirli bir süre verilmesi bakımından ihtiyati hacze nazaran zaman olan bir yol olduğu, ihtiyati haczin daha etkili ve daha ağır hukuki sonuçları olan bir araç olduğu ifadelerine yer verilmiştir.

Anayasa Mahkemesi teminat istenmesi için sadece vergi incelemesine başlanılmış olmasının yeterli olmadığına Kanunda belirtilen hâllere temas eden bir kamu alacağının salınması için gerekli işlemlere başlanılmış olmasının gerektiğine değinmiştir. Buna göre vergi incelemesine yetkili memurlar tarafindan vergi ziyaı ya da kaçakçılık sayılan hâllerin varlığına işaret eden bazı işlemler yapılmalıdır. Bu bakımdan itiraz konusu birinci fikrada belirtilen durumların varlığı hâlinde tahsil dairesinin teminat istemesinin ancak vergi incelemesi sırasında somut birtakım verilere dayanılması durumunda ve yapılan ilk hesaplamalara göre belirlenen miktarla sınırlı olarak mümkün olduğuna işaret edilmiştir. Anayasa Mahkemesi kararında, bu fikra hükmüne göre vergi incelemesi yapılmadan tahsil dairesi tarafindan takdire dayalı şekilde teminat istenmesinin mümkün olamayacağ 1 ifade edilmiştir.

Ayrıca kararda, teminata konu alacak henüz tahakkuk etmemiş bir kamu alacağı niteliğinde olmakla birlikte teminat istendiği sirada devam eden bir vergi incelemesinin varlığı ve verginin tarhiyatına ilişkin ön işlemlere başlanılmış olduğu gözetildiğinde söz konusu incelemenin tamamlanmasının ve alacağın tahakkuk ettirilmesinin alacağın varlığını belirsiz kılacak uzun bir süreci gerektirmeyeceği ifade edilmektedir. Diğer taraftan vergi incelemesinin tamamlanıp alacağın tahakkuk ettirilmesinin makul karşılanabilecek bir zaman aralığını aşması hâlinde ise teminatın idarece kaldırılması, kaldırılmadığ 1 takdirde meydana gelecek zararların dava yoluyla tazmin edilmesinin her zaman mümkün olacağı belirlemesi yapılmaktadır. Ayrıca şahsi kefaletin teminat olarak gösterilebilmesi, teminat gösterilecek mal varlığı değerlerinin seçilebilmesi, değiştirilebilmesi gibi mükellef lehine getirilen kolaylıklar ile teminat istenmesine ilişkin işlemin iptali veya uğranan zararların tazmini talebiyle yargı yoluna başvurulabileceği hususlarını göz önünde bulunduran Mahkeme, kural kapsamında düzenlenen teminat kurumunun uygulanması ile mülkiyet hakkına yapılan müdahalenin ölçülü olduğu görüşüne ulaşmıştır.

Sonuç olarak mahkemenin gerekçeli kararında teminat kurumunun kamu yararı sağlanması amacına yönelik olduğu ifade edilmiştir. Bu doğrultuda niteliği gereği kamu alacaklarının özel hukuk ilişkilerinden doğan alacaklara göre daha ayrıcalıklı olduğuna, tahsilin riske girmesi nedeniyle kurallar kapsamında uygulanan tedbirlerin somut verilere dayanması gerek- 
tiğine ve geçici niteliği ile mükellefler lehine getirilen kolaylıklar da göz önüne alındığında kuralla getirilen sınırlamanın adalet ve hakkaniyete dolayısıyla da hukuk devleti ilkesine aykırı bir yönünün bulunmadığına hükmedilmiştir.

\section{SONUÇ}

Kamu hizmetlerinin yürütülebilmesi adına kamu alacaklarının zamanında ve eksiksiz bir surette tahsil edilmesi ihtiyacı, kamu alacaklısına önemli bir sorumluluk yüklemektedir. 6183 sayılı Kanunda kamu alacağının cebri takip ve tahsil sürecine ilişkin hukuki çerçeve belirlenirken söz konusu sorumluluğu taşıyan kamu alacaklısına özel hukuki araçlar kullanabilme yetkisi verilmiştir.

Kamu alacaklısı idari bir organ olarak idari işlemler yoluyla alacağını tahsil edebilmektedir. Diğer taraftan henüz mali ve hukuki açıdan kesinlik kazanmamış bir kamu alacağı için alacağın tahsiline engel olabilecek tehlikelerin varlığ 1 belirlemesiyle, tahsili güvenceye bağlayan önlemler kulanılabilmektedir. 6183 sayılı Kanunda yer alan teminat kurumu bu çerçevede cebri takip ve tahsile yönelik bir işlem olmayıp, alacak henüz tahsil aşamasina gelinmeden uygulanabilen geçici bir önlemdir. Bu yolla henüz tarh ve tebliğ etmemiş, tahakkuk aşamasına gelinmemiş bir alacak beklentisi için kamu borçlusundan veya belki de bu sıfatı taşımayacak olan bir kişiden tahsilin tehlikede olduğu düşüncesiyle teminat istenmektedir.

Teminat bir taraftan kamu alacağının tahsilini güvenceye bağlarken diğer taraftan kamu borçlusu lehine düzenlemeler içermektedir. Teminat kurumunun Kanun sistematiğinde aynı bölümde düzenlenmiş olan ihtiyati haciz ve ihtiyati tahakkuka temas eder yönü belli noktalarda çakışmalara vesile olmaktadır. Ancak 6183 sayılı Kanun m.9-12 arasında düzenlenmiş olan teminat diğer koruma önlemlerinden ayrı ve bağımsız bir surette varlığını devam ettirebilme ve uygulanabilme hukuki dayanağına sahiptir. 


\section{KAYNAKÇA}

Alpaslan, Mustafa/Şentürk, Akın Gencer: "Vergi İncelemelerinde İhtiyati Haciz İhtiyati Tahakkuk Sonucunda Teminat Talep Edilebilmesi İçin VUK 344 ve 359 Maddelerinin Mevcudiyeti Topluca Gereklidir", Legal Mali Hukuk Dergisi, Say1:53, 2009. (923-927).

Arkan, Sabih: "Teminat Mektubu Veren Bankanın Hukuki Durumu”, Banka ve Ticaret Hukuku Dergisi, Cilt:16, Say1:4, 1992. (59-84).

Arslan, Cem Barlas: "Kamu Alacağını Güvence Altına Alınmasında Teminat Uygulaması”, Legal Mali Hukuk Dergisi, Sayı:60, 2009. (2468-2476).

Arslaner, Hakan: 6183 sayılı Kanun Kapsamında Kamu Alacaklarının Haciz Yoluyla Tahsili, (Yetkin), Ankara 2010.

Bahçeci, Barış: Kamu Alacağının Takip Hukuku, (Seçkin), Ankara 2019.

Barlass, İrfan: Kamu Alacaklarının Haciz Yoluyla Takibi, (Onikilevha), İstanbul 2017.

Bayraklı, Hasan Hüseyin: Vergi İcra Hukuku, Afyonkarahisar 2012.

Baysal, Eda: "Vergi Hukuku Yönünden Amme Alacağının Korunmasına Dair Güvence Önlemlerinden Olan "Teminat İsteme" Uygulamasında "Yetki" ve "Neden" Unsurlarının Tahlili", Legal Mali Hukuk Dergisi, Say1: 54, 2009. (1165-1175).

Candan, Turgut: Açıklamalı Amme Alacaklarının Tahsil Usulü Hakkında Kanun, Güncelleştirilmiş 3. Baskı, (Mali Akademi Yayınları), Ankara 2007.

Coşkun, Mahmut: Açıklamalı-İçtihatlı Amme Alacaklarının Tahsil Usulü Hakkında Kanun, Güncelleştirilmiş 2. Baskı, (Seçkin), Ankara 2013.

Çelik, Binnur: "Kamu Alacaklarını Güvence Atına Alan Teminat, İhtiyati Haciz ve İhtiyati Tahakkuk Uygulamaları ve Kanun Değişikliği Önerileri”, Amme Alacaklarının Tahsil Usulü Hakkında Kanun İle Bağlantılı Problemler ve Çözüm Paneli, (İstanbul Vergi Merkezi), İstanbul 2018. (1-10). (Teminat).

Çelik, Binnur: Kamu Alacaklarının Takip ve Tahsil Hukuku, 3.Bask1, (Onikilevha), İstanbul 2018. (Kamu Alacakları).

Doğrusöz, Bumin: "Vergi Dairesinin Teminat Talebi”, Dünya Gazetesi, 13 Mayis 2015, https://www.dunya.com/kose-yazisi/vergi-dairesininteminat-talebi/23939. (20.02.2020). 
Gerçek, Adnan: Kamu Alacaklarının Tahsil Hukuku, 5.Baskı, (Ekin), Bursa 2017. (Kamu Alacakları).

Gerçek, Adnan: Türk Mali Hukukunda Teminat, (Seçkin), Ankara 2013. (Teminat).

Gözler, Kemal/Kaplan, Gürsel: İdare Hukuku Dersleri, Güncellenmiş 21. Bask1, (Ekin), Bursa 2019.

Gülseven, Mustafa: Açıklamalı- İçtihatlı Amme Alacaklarının Tahsil Usulü Hakkında Kanun, (Seçkin), Ankara 1999.

Kaneti, Selim/Ekmekçi, Esar/Güneş, Gülsen/Kaşıkçı, Mahmut: Vergi Hukuku, (Filiz Kitabevi), İstanbul 2019.

Karadağ, Neslihan Coşkun: "Vergi Alacağının Güvence Altına Alınmasında Teminat, İhtiyati Haciz ve İhtiyati Tahakkuka İlişkin Özellikli Durumlar”, Maliye Dergisi, Say1: 162, 2012. (238-255).

Karakoç, Yusuf: Genel Vergi Hukuku, Gözden Geçirilmiş ve Güncellenmiş 2. Bask1, (Yetkin), Ankara 2019. (Genel Vergi).

Karakoç, Yusuf: Kamu İcra Hukuku, (Yetkin), Ankara 2016. (Kamu İcra).

Kızılot, Şükrü/Kızılot, Zuhal: Vergi İhtilafları ve Çözüm Yolları, Güncellenmiş 15. Bask1, (Yaklaşım), Ankara 2009.

Koçak, Muhsin: Vergi-İcra Hukuku, Güncellenmiş 2. Baskı, (Seçkin), Ankara 2018.

Öncel, Mualla/Kumrulu, Ahmet/Çă̆an, Nami/Göker, Cenker: Vergi Hukuku, Gözden Geçirilmiş ve Değişiklikler İşlenmiş 28. Bask1, (Turhan Kitabevi), Ankara 2019.

Öner, Erdoğan: Vergi Hukuku, Gözden Geçirilmiş ve Güncellenmiş 11. Baskı, (Seçkin), Ankara 2019.

Şeker, Sakıp: "Vergi İncelemelerine Dayanan İhtiyati Haciz Uygulamalarının Mükellef Hakları Yönünden Değerlendirilmesi”, Legal Mali Hukuk Dergisi, Sayı:37, 2008. (159-162).

Şentürk, Akın Gencer: “Amme Alacaklarının Korunması Yöntemlerinden "Teminat İsteme" Uygulamasının İhtiyati Tahakkuk-İhtiyati Haciz Müesseseleri İle Bağlantısının Ortaya Konulması ve Bir İdari İşlem Olarak Vergi Hukuku Yönünden İrdelenmesi”, http://agencerhukuk.com/014.pdf (20.02.2020).

Şenyüz, Doğan: “İflasta Vergi Alacakları ve Sırası”, Ankara Üniversitesi Hukuk Fakültesi Dergisi, Cilt: 67, Sayı: 4, 2018. (891-952). 
Şimşek, Edip: Amme Alacakları Tahsil Usulü Kanun Şerhi Uygulama ve İçtihatlar, Yeniden Gözden Geçirilmiş Güncellenmiş 2. Baskı, (Alfa Basım Yayım Dağıtım), İstanbul 1996.

Taşkan, Yusuf Ziya: Vergi Hukuku, Genişletilmiş ve Gözden Geçirilmiş 2. Bask1, (Adalet), Ankara 2019.

Taylar, Yıldırım: "Kamu Alacakları İçin Güvence Önlemi Olarak Teminat ve Teminat-İhtiyati Haciz İlişkisinden Kaynaklanan Sorunları", Mali Pusula, S:48, 2008. (68-87).

Ünlü, M. Cengiz: Açıklamalı-Içtihatlı Amme Alacaklarının Tahsil Usulü Hakkında Kanun, (Seçkin), Ankara 1995.

Ünsal, Hilmi: Amme Alacaklarının Takip ve Tahsili, Damga Vergisi ve Harçlar, (Seçkin), Ankara 2019.

Üstün, Gül: İdare Hukuku Boyutuyla 6183 Sayılı Amme Alacaklarının Tahsil Usulü Hakkında Kanun Uygulamalarında Görev Sorunu, (XII Levha), İstanbul 2013.

Üstün, Ümit Süleyman: "Kamu Alacaklarının Korunması Bakımından Teminat Kurumu", Vergi Sorunları Dergisi, Sayı:182, 2003. (146-156). (Teminat).

Üstün, Ümit Süleyman: Kamu Alacaklarında Rüçhan Hakkı, (Legal), İstanbul 2013. (Kamu Alacakları).

Yapar, Burcu Kuzucu: Türk Hukukunda Kamu Alacaklarını Güvence Altına Alan Önlemler, (Onikilevha), İstanbul 2020.

Yerlikaya, Gökhan Kürşat: "Türk Vergi İcra Hukukunda "Devlet" Kavramının Niteliği ve İşlevi”, Kadir Has Üniversitesi Hukuk Fakültesi Dergisi, Cilt:6, Say1:2, 2018. (243-252.) (Vergi İcra).

Yerlikaya, Gökhan Kürşat: Açıklamalı ve İçtihatlı 6183 Sayılı Amme Alacaklarının Tahsil Usulü Hakkında Kanun Şerhi, (XII Levha), İstanbul 2012. (Şerh).

www.kazanc1.com.

www.legalbank.net. 